\title{
Trust, Trustworthiness, and Trust Propensity: A Meta-Analytic Test of Their Unique Relationships With Risk Taking and Job Performance
}

\author{
Jason A. Colquitt, Brent A. Scott, and Jeffery A. LePine \\ University of Florida
}

\begin{abstract}
The trust literature distinguishes trustworthiness (the ability, benevolence, and integrity of a trustee) and trust propensity (a dispositional willingness to rely on others) from trust (the intention to accept vulnerability to a trustee based on positive expectations of his or her actions). Although this distinction has clarified some confusion in the literature, it remains unclear (a) which trust antecedents have the strongest relationships with trust and (b) whether trust fully mediates the effects of trustworthiness and trust propensity on behavioral outcomes. Our meta-analysis of 132 independent samples summarized the relationships between the trust variables and both risk taking and job performance (task performance, citizenship behavior, counterproductive behavior). Meta-analytic structural equation modeling supported a partial mediation model wherein trustworthiness and trust propensity explained incremental variance in the behavioral outcomes when trust was controlled. Further analyses revealed that the trustworthiness dimensions also predicted affective commitment, which had unique relationships with the outcomes when controlling for trust. These results generalized across different types of trust measures (i.e., positive expectations measures, willingness-to-be-vulnerable measures, and direct measures) and different trust referents (i.e., leaders, coworkers).
\end{abstract}

Keywords: trust; trustworthiness, commitment, integrity, citizenship

Trust has become an important topic of inquiry in a variety of disciplines, including management, ethics, sociology, psychology, and economics. Although this multidisciplinary perspective has created a breadth that strengthens the trust literature (Bigley \& Pearce, 1998; Rousseau, Sitkin, Burt, \& Camerer, 1998), it also has created confusion about the definition and conceptualization of the trust construct. For example, some scholars view trust as a behavioral intention (Mayer, Davis, \& Schoorman, 1995; McKnight, Cummings, \& Chervany, 1998; Rousseau et al., 1998) or an internal action, similar to choosing, judging, or preferring (e.g., Lewis \& Weigert, 1985; Riker, 1971). Others view trust as synonymous with trustworthiness, discussing trust in the context of personal characteristics that inspire positive expectations on the part of other individuals (e.g., Butler \& Cantrell, 1984; McKnight et al., 1998). Still others view trust as a facet of personality that develops early in life and remains relatively stable through adulthood (Rotter, 1967; Webb \& Worchel, 1986). Finally, others treat trust as a synonym for cooperation or risk taking (e.g., Kee \&

Jason A. Colquitt, Brent A. Scott, and Jeffery A. LePine, Department of Management, Warrington College of Business Administration, University of Florida.

An earlier version of this article was presented in R. C. Mayer and B. A. Scott's (Chairs), Do you trust me? Examining antecedents of trust in task contexts, symposium conducted at the meeting of the Academy of Management, New Orleans, Louisiana, August 2004. We thank Kurt Dirks and Roger Mayer for their helpful comments on that draft.

Correspondence concerning this article should be addressed to Jason A. Colquitt, Department of Management, Warrington College of Business Administration, University of Florida, P.O. Box 117165, Gainesville, FL 32611-7165. E-mail: colquitt@ufl.edu
Knox, 1970; Lewis \& Weigert, 1985; Zand, 1972), often operationalizing it using cooperative choices in a dilemma game (e.g. Deutsch, 1958, 1960).

Two articles published in the mid-to-late 1990s attempted to clarify some of this confusion (Mayer et al., 1995; Rousseau et al., 1998). Mayer et al.'s integrative model defined trust as the willingness of a trustor to be vulnerable to the actions of a trustee based on the expectation that the trustee will perform a particular action. Similarly, Rousseau et al.'s cross-discipline review defined trust as a psychological state comprising the intentions to accept vulnerability based on positive expectations of the actions of the trustee. Both definitions have two primary components. One component is the intention to accept vulnerability, which is rooted in several earlier conceptualizations of trust (e.g., Boon \& Holmes, 1991; Deutsch, 1958; Govier, 1994; Zand, 1972). The other component is positive expectations, also present in several earlier conceptualizations of trust (e.g., Barber, 1983; Boon \& Holmes, 1991; Cook \& Wall, 1980; Golembiewski \& McConkie, 1975 Read, 1962; Roberts \& O’Reilly, 1974).

In addition to clarifying what trust is, Mayer et al.'s (1995) integrative model clarified what trust is not. First and foremost, Mayer et al.'s model separated trust from trustworthiness, with three characteristics of the trustee (ability, benevolence, and integrity) appearing as antecedents of trust. This structure, which has been adopted in subsequent models (McKnight et al., 1998; Ross \& LaCroix, 1996; M. Williams, 2001) echoes Gabarro's (1978) suggestion that trustworthiness is a multifaceted construct that captures the competence and character of the trustee (see also Butler, 1991; Butler \& Cantrell, 1984; Kee \& Knox, 1970). In addition, Mayer et al. drew a distinction between trust as a situational state and trust as a personality variable, with trust propensity 
defined as a stable individual difference that affects the likelihood that a person will trust (see also Rotter, 1967; Stack, 1978).

Although the separation of trust, trustworthiness, and trust propensity has clarified the structure of the literature, five critical questions remain unanswered. First, do all three facets of trustworthiness - ability, benevolence, and integrity — have significant, unique relationships with trust, and how strong are those relationships? Second, does trust propensity remain important once trustworthiness can be gauged, or does its effect on trust disappear when trustworthiness is controlled? Third, are trustworthiness and trust propensity important only because they help inspire trust, meaning that trust fully mediates their effects on relevant consequences? Fourth, how does the approach used to measure trust alter its relationship with antecedents and consequences? Scholars have used a number of approaches to measure trust (e.g., Cook \& Wall, 1980; Driscoll, 1978; Earley, 1986; Mayer \& Davis, 1999; Read, 1962; Roberts \& O'Reilly, 1974), and it remains unclear whether the nomological network for trust varies across those approaches. Fifth, do trust relationships vary according to whether the trustee is a leader versus a coworker? Past research has drawn a distinction between trust in leaders and trust in coworkers (Dirks \& Ferrin, 2002), yet Mayer et al.'s (1995) model is purported to be equally relevant to either sort of trust referent.

The present study used meta-analytic structural equation modeling (Viswesvaran \& Ones, 1995) to explore these five questions. Although the trust literature previously has been the subject of a meta-analysis, that review did not address these specific research questions. Dirks and Ferrin (2002) meta-analyzed the results of 93 articles examining the antecedents (e.g., leadership style, participation in decision making) and consequences (e.g., organizational commitment, job performance) of trust. Although their review provided a useful and still timely quantitative summary of the literature, their decisions about conceptualizing trust were not necessarily made with Mayer et al.'s (1995) model in mind. As a result, what they coded as trust often represented, in a Mayer et al. sense, an amalgam of trust, ability, benevolence, and integrity. This approach makes it difficult to estimate the relationships between ability, benevolence, integrity, and trust and to explore their unique relationships with outcomes. In addition, Dirks and Ferrin's review focused on trust in leaders, leaving open the possibility that the antecedents and consequences of trust differ from leader referents to coworker referents. Our article therefore provides a useful complement to Dirks and Ferrin's review by exploring a different set of research questions.

In exploring the five aforementioned research questions, we focused on two broad outcomes of trust: risk taking and job performance. Recall that some scholars have equated trust with behaviors that convey risk taking (e.g., Deutsch, 1958, 1960; Kee \& Knox, 1970; Lewis \& Weigert, 1985; Zand, 1972). In Mayer et al.'s (1995) formulation, the distinction between trust and risk taking reflects the distinction between a willingness to be vulnerable and actually becoming vulnerable. Risk taking therefore stands as the most proximal behavioral outcome or expression of trust (Mayer et al., 1995; Ross \& LaCroix, 1996). With respect to job performance, trust is believed to affect the manner in which a trustor allocates resources when interacting with the trustee (Dirks $\&$ Ferrin, 2002; Mayer \& Gavin, 2005). If a trustor is willing to be vulnerable to leaders and colleagues, the trustor is free to focus full attention on job tasks as opposed to diverting energy to monitor- ing. Trust also allows the development of a more effective exchange relationship between the trustor and trustee (Blau, 1964), which encourages more beneficial performance behaviors on the job. Consistent with Rotundo and Sackett's (2002) multidimensional model of job performance, we explored three specific performance facets: task performance (Borman \& Motowidlo, 1993), citizenship behavior (Smith, Organ, \& Near, 1983), and counterproductive behavior (Sackett \& DeVore, 2001).

\section{Trust Antecedents: Trustworthiness and Trust Propensity}

\section{Trustworthiness}

The definitions of trust offered by Mayer et al. (1995) and Rousseau et al. (1998) both include an expectation that another party will perform a particular action. One driver of that expectation is trustworthiness, as Lewis and Weigert (1985) noted:

First, trust is based on a cognitive process which discriminates among persons and institutions that are trustworthy, distrusted, and unknown. In this sense, we cognitively choose whom we will trust in which respects and under which circumstances, and we base the choice on what we take to be "good reasons," constituting evidence of trustworthiness. (p. 970)

In the words of Flores and Solomon (1998), "In the ideal case, one trusts someone because she is trustworthy, and one's trustworthiness inspires trust" (p. 209). Clearly, then, the concept of trustworthiness is central to understanding and predicting trust levels.

Gabarro (1978) conducted a longitudinal study of how managers develop working relationships with their subordinates. He conducted interviews with newly appointed managers over a 3-year time period, focusing specifically on the "bases of trust" (p. 295). One of those bases was competence or ability, which captures the knowledge and skills needed to do a specific job along with the interpersonal skills and general wisdom needed to succeed in an organization (Gabarro, 1978). Ability has become one of the more commonly discussed components of trustworthiness (Barber, 1983; Butler, 1991; Butler \& Cantrell, 1984; Gabarro, 1978; Kee \& Knox, 1970; Mayer et al., 1995). Another of those bases was character, a multifaceted construct that subsumes concepts like honesty, fairness, openness, caring motives and intentions, and predictability. Mayer et al.'s model separates character into two components. The first component is benevolence, defined as the extent to which a trustee is believed to want to do good for the trustor, apart from any profit motives, with synonyms including loyalty, openness, caring, or supportiveness (Mayer et al., 1995). The second component is integrity, defined as the extent to which a trustee is believed to adhere to sound moral and ethical principles, with synonyms including fairness, justice, consistency, and promise fulfillment.

Although the relevance of ability, benevolence, and integrity may seem intuitive, it remains unclear whether each has a unique impact on trust levels. It may be that either ability or character is sufficient for fostering trust but that both are not needed. Although that expectation seems reasonable, there are theoretical reasons to expect ability and character to have unique relationships with trust. First, ability captures the "can-do" component of trustworthiness by describing whether the trustee has the skills and abilities needed 
to act in an appropriate fashion. In contrast, the character variables capture the "will-do" component of trustworthiness by describing whether the trustee will choose to use those skills and abilities to act in the best interest of the trustor. Such "can-do" and "will-do" explanations for volitional behavior tend to exert effects independent of one another (e.g., Campbell, 1990).

It also may be that the effects of the two character facetsbenevolence and integrity - are redundant with each another. In support of this notion, some studies using both variables have failed to uncover significant, unique effects for both (Jarvenpaa, Knoll, \& Leidner, 1998; Mayer \& Gavin, 2005). However, there are theoretical reasons to expect benevolence and integrity to have unique relationships with trust. Integrity represents a very rational reason to trust someone, as a sense of fairness or moral character provides the kind of long-term predictability that can help individuals cope with uncertainty (Lind, 2001). In contrast, benevolence can create an emotional attachment to the trustee, with caring and supportiveness fostering a sense of positive affect. Trust scholars have suggested that affect-based sources of trust can supplement more cognition-based sources such as ability or integrity (Flores \& Solomon, 1998; Lewicki \& Bunker, 1996; Lewis \& Weigert, 1985; McAllister, 1995; Rousseau et al., 1998; Shapiro, Sheppard, \& Cheraskin, 1992; M. Williams, 2001). In summary, our study provides the first meta-analytic summary of the relationships between ability, benevolence, integrity, and trust. We used that meta-analytic data to test the following prediction:

Hypothesis 1a-c: The (a) ability, (b) benevolence, and (c) integrity components of trustworthiness each have significant, unique relationships with trust.

\section{Trust Propensity}

Of course, decisions about trust must often be made before enough time has passed to gather data on trustworthiness. Kee and Knox (1970) argued that trust depends not just on past experience but also on dispositional factors such as personality. Rotter (1967) was among the first to discuss trust as a form of personality, defining interpersonal trust as a generalized expectancy that the words or promises of others can be relied on (see also Rosenberg, 1956; Rotter, 1971, 1980). This personality-based form of trust has been referred to by other scholars as dispositional trust (Kramer, 1999), generalized trust (Stack, 1978), and trust propensity (Mayer et al., 1995). McKnight et al. (1998) argued that trust propensity has taken on a new importance as cross-functional teams, structural reorganizations, and joint ventures create new working relationships more frequently. After all, trust propensity is likely to be the most relevant trust antecedent in contexts involving unfamiliar actors (Bigley \& Pearce, 1998).

However, an unanswered question is whether trust propensity continues to impact trust once trustworthiness has been gauged. Becker (1996) noted that trust should always be connected to "good estimates of others' trustworthiness" (p. 47). However, Govier (1994) argued that trust propensity creates a filter that alters interpretations of others' actions. In this way, “observations are theory-laden" (p. 244), retaining the impact of trust propensity even after trustworthiness can be inferred. Lewis and Weigert (1985) made a similar claim, arguing that information on trustworthiness only opens the door to trust without actually constituting it. The cognitive element in trust is characterized by a cognitive "leap" beyond the expectations that reason and experience alone would warrant-they simply serve as the platform from which the leap is made. (p. 971)

Trust propensity may be the key driver of the form and shape of that leap, affecting trust even in the presence of trustworthiness information. We therefore used meta-analytic data to test the following prediction:

Hypothesis 2: Trust propensity is positively related to trust, controlling for ability, benevolence, and integrity.

\section{Trust Consequences: Risk Taking and Job Performance}

As noted earlier, Mayer et al.'s (1995) model casts trust as the most proximal predictor of risk taking and related outcomes (see also Kee \& Knox, 1970; Ross \& LaCroix, 1996). Other models view trust as a proximal antecedent of a variety of job performance behaviors, including task performance, citizenship behavior, and counterproductive behavior (Dirks \& Ferrin, 2002; G. R. Jones \& George, 1998; M. Williams, 2001). Many of those models also predict that trust completely mediates the effects of trustworthiness and trust propensity on those outcomes (Kee \& Knox, 1970; Mayer et al., 1995; Ross \& LaCroix, 1996; M. Williams, 2001). From this perspective, trustworthiness and trust propensity are important only because they help inspire trust - they lack any unique or independent effects on risk taking or job performance.

Although the full mediation view represents the consensus of most trust models, that structure contradicts theorizing in the literature on social exchange. Blau (1964) distinguished between two types of exchange relationships: (a) economic exchanges, which are contractual in nature and involve the exchange of exact quantities specified in advance, and (b) social exchanges, which involve the exchange of diffuse, future obligations that are vaguely specified and occur over a more open-ended time frame. Consistent with Gouldner's (1960) norm of reciprocity, the parties involved in social exchanges understand that a favor received in the present creates an expectation of some repayment in the future. For example, caring actions on the part of one exchange partner create a sense of indebtedness on the part of the other, which may lead to beneficial attitudes and behaviors directed toward the caring partner.

Trust concepts are a critical component of the social exchange literature in two primary respects. First, the absence of any formal contract or specified repayment schedule creates a built-in vulnerability, with one party risking the possibility that the other will fail to meet obligations. As a result, social exchange relationships cannot develop in the absence of trust (Blau, 1964). For this reason, scholars sometimes use trust levels as an indicator of the existence of a social exchange relationship (Aryee, Budhwar, \& Chen, 2002; Konovsky \& Pugh, 1994; Shore, Tetrick, Lynch, \& Barksdale, 2006). Second, many of the facets of trustworthiness can be viewed as currencies that help create a social exchange. For example, trustworthiness facets such as demonstrating concern and support or acting based on sound principles can be viewed as actions that should engender a motivation to reciprocate on the part of an exchange partner. Thus, from a social exchange perspective, 
trustworthiness inspires a social exchange relationship with trust levels acting as one indicator of that relationship.

However, a number of other constructs also serve as indicators of a social exchange relationship_constructs that could themselves act as mediators of trustworthiness-outcome relationships. For example, Meyer and Allen (1997) distinguished between affective commitment, which reflects a desire to remain a member of a collective because of an emotional attachment, and continuance commitment, which reflects an attachment based in economic investments and costs. Affective commitment indicates the existence of a social exchange relationship, whereas continuance commitment indicates the existence of an economic exchange relationship (Mowday, Porter, \& Steers, 1982; Shore et al., 2006). A number of other constructs also have been described as indicators of social exchange relationships, including felt obligation, which reflects the feeling that an individual owes the exchange partner a maximum amount of energy and effort (Eisenberger, Armeli, Rexwinkel, Lynch, \& Rhoades, 2001), and psychological contract fulfillment, which reflects the degree to which a party perceives that their exchange partner has fulfilled promised obligations (Aselage \& Eisenberger, 2003; Robinson \& Rousseau, 1994; Turnley, Bolino, Lester, \& Bloodgood, 2003). To the extent that trustworthiness predicts outcomes through the mechanisms of affective commitment, felt obligation, psychological contract fulfillment, and so forth, the mediating role of trust will only be partial. Our review focuses specifically on the mediating role of affective commitment given that it has been included in trust studies more frequently than the other social exchange indicators.

Social exchange arguments also can be used to support direct effects for trust propensity on outcomes, even when controlling for trust. In his research on the construct, Rotter (1980) suggested that individuals with a high trust propensity would themselves act more trustworthy. That is, "high trustors" would exhibit a dispositional tendency to act in a cooperative, prosocial, and moral manner across contexts and across situations. Empirical research has tended to support this claim, as higher scores on trust propensity tend to be associated with increased honesty, increased compliance, increased help offering, and decreased cheating (Rotter, 1971, 1980; Stack, 1978; Webb \& Worchel, 1986). These results suggest that high trustors may be better at building social exchange relationships because they are more prone to adhering to the norm of reciprocity (Gouldner, 1960) and are more likely to commit to the long-term protection of the exchange relationship. If so, such individuals should be capable of building a more expansive social network that could bring them the information and support needed to improve their decision making and performance (Burt, 1992; Wayne, Shore, \& Liden, 1997). We therefore used meta-analytic data to test the following predictions regarding the mediating role of trust:

Hypothesis $3 a-c$ : The relationships between (a) ability, (b) benevolence, (c) integrity, and risk taking and job performance are partially mediated by trust.

Hypothesis 4: The relationships between trust propensity and risk taking and job performance are partially mediated by trust.
Hypothesis 5a-c: The relationships between (a) ability, (b) benevolence, (c) integrity, and risk taking and job performance are partially mediated by affective commitment.

Hypothesis 6: The relationships between trust propensity and risk taking and job performance are partially mediated by affective commitment.

\section{Moderators of Trust Relationships}

In the course of testing our hypotheses, our article provides a meta-analytic summary of the relationships between trust, its antecedents (ability, integrity, benevolence, trust propensity), and its consequences (risk taking, task performance, citizenship behavior, counterproductive behavior). As noted earlier, many of these relationships have never been summarized in a meta-analytic review, as Dirks and Ferrin (2002) did not include antecedents such as ability or consequences such as risk taking and counterproductive behavior. Our article also examines two moderators of trust effects: the nature of the trust measure and the referent used for trust (i.e., leader vs. coworker).

With respect to trust measurement, we examine three types of measures that have been used in assessing trust relationships. Some scholars have used scales that focus on the positive expectations component of trust (e.g., Cook \& Wall, 1980; Luo, 2002; McAllister, 1995; Read, 1962; Roberts \& O'Reilly, 1974). Other scholars have relied on scales that focus on the willingness-to-bevulnerable component (e.g., Jarvenpaa et al., 1998; Mayer \& Davis, 1999; Mayer \& Gavin, 2005). Still other scholars have used measures that simply ask people to rate the extent to which they "trust," referred to here as direct measures (e.g., Ball, Trevino, \& Sims, 1993; Brockner, Siegel, Daly, Tyler, \& Martin, 1997; Driscoll, 1978; Earley, 1986). The degree to which these different measures affect relationships with trust is unclear.

With respect to trust referent, some studies have focused on trust in a direct leader or the general leadership of an organization (e.g., Davis, Schoorman, Mayer, \& Tan, 2000; Kirkpatrick \& Locke, 1996), whereas other studies have focused on trust in one or more coworkers and colleagues (Luo, 2002; Tjosvold, Andrews, \& Struthers, 1991). Mayer et al. (1995) suggested that their integrative model of trust "is applicable to a relationship with another identifiable party who is perceived to act and react with volition toward the trustor" (p. 712). However, it remains an empirical question whether trust relationships vary when that identifiable party is leader based or coworker based.

\section{Method}

\section{Literature Search}

The first step in conducting the meta-analyses used to test our hypotheses was the identification of relevant articles. We performed a literature search using the PsycINFO and Web of Science databases using trust as the keyword. We also obtained relevant paper presentations from recent scholarly meetings and performed a Google search to look for unpublished working papers. To be included in our meta-analyses, articles had to assess some trustrelevant variable (whether trustworthiness, trust propensity, or trust itself) and involve an adult-age sample working in a taskfocused environment. 
Our search uncovered 249 articles that explored a relationship between a trust-relevant variable and at least one other antecedent or consequence. We inspected those articles to ensure that they possessed codable information, meaning that they contained some zero-order effect size that could be translated into a correlation coefficient. Such translations often involved $F$ statistics or $t$ statistics corresponding to zero-order effects, or mean and standard deviation information across experimental conditions. However, studies that included only partial or semipartial regression coefficients, or mean data without accompanying standard deviations, were excluded. We also excluded studies that examined trust relationships at higher levels of analysis using aggregate data (e.g., Jarvenpaa et al., 1998), as it may be inappropriate to combine those data with individual level studies (Ostroff \& Harrison, 1999). These and other exclusions resulted in a final set of 119 articles representing 132 independent samples. These articles are marked in the References section by an asterisk.

\section{Coding Procedures}

Given the judgment calls inherent in meta-analyses, all coding was performed by dyads formed from the study's three authors. When a disagreement arose, the author who was not part of the dyad was brought in to discuss the coding question, though this was rarely needed. We used the definitions, synonyms, and examples from Mayer et al.'s (1995) conceptual article and Mayer and Davis's (1999) trustworthiness measure to categorize each article's variables into the ability, benevolence, and integrity categories. Table 1 summarizes this information. Variables were coded as ability if they captured trustee skills or competencies. Specific variables that were grouped into this coding category included scales designed to assess ability, like, "competence," "expertise," "knowledge," and "talent" (Mayer \& Davis, 1999). Variables were categorized as integrity if they referred to the trustee's adherence to sound moral and ethical principles. Specific variables that were grouped into this coding category included scales designed to assess integrity, like, "promise keeping," "credibility," and "procedural justice" (Mayer \& Davis, 1999). Procedural justice was included because its focus on the consistency, bias suppression, and ethicality of decision making (Leventhal, 1980) matches Mayer et al.'s discussion of integrity as consistency of actions and a strong sense of justice. Procedural justice concepts also are included in three of Mayer and Davis's integrity items. Variables were coded as benevolence if they assessed the degree to which the trustee wanted to do good for the trustor. Specific variables that were grouped into this coding category included scales designed to assess benevolence, like "openness," "loyalty," "concern," and "perceived support" (Mayer \& Davis, 1999). Perceived support was included because its focus on caring, valuing, showing concern, and helping the focal individual (Eisenberger et al., 2001) matches Mayer et al.'s (1995) discussion of benevolence as caring and receptivity. Perceived support concepts are also included in four of Mayer and Davis's benevolence items.

Variables were coded as trust propensity if they measured a general tendency to trust others. The most commonly used measures of trust propensity included Rotter's (1967) interpersonal trust scale, Rosenberg's (1956) faith-in-people scale, the trust facet of the NEO PI-R Agreeableness scale (Costa \& McCrae, 1992), and Mayer and Davis's (1999) trust propensity scale.

With respect to trust, several studies have used positive expectations measures with exemplar items like "How confident do you feel that your superior keeps you fully and frankly informed about things that might concern you?" (Read, 1962; see also Carson, Madhok, Varman, \& John, 2003; Clegg, Unsworth, Epitropaki, \& Parker, 2002; Cook \& Wall, 1980, Peers subscale; Luo, 2002). For the most part, these measures have assessed positive expectations in reference to the actions and behaviors of the trustee. It is important to note, however, that other positive expectations measures instead referenced expectations to the qualities and charac-

Table 1

Coding Guidelines for Ability, Benevolence, and Integrity

Coding category

Ability: "that group of skills, competencies, and characteristics that enable a party to have influence within some specific domain" (Mayer et al., 1995, p. 717)

Benevolence; "the extent to which the trustee is believed to want to do good to the trustor, aside from an egocentric profit motive" (Mayer et al., 1995, p. 718).

Integrity: "the perception that the trustee adheres to a set of principles that the trustor finds acceptable" (Mayer et al., 1995, p. 719).

Mayer et al. (1995) synonyms

[The trustee] is very capable of performing [the trustee's] job.

[The trustee] is known to be successful at the things [the trustee] tries to do.

[The trustee] has much knowledge about the work that needs done.

I feel very confident about [the trustee's] skills.

[The trustee] has specialized capabilities that can increase our performance.

[The trustee] is well qualified.

[The trustee] is very concerned with my welfare.

My needs and desires are very important to [the trustee].

[The trustee] would not knowingly do anything to hurt me.

[The trustee] really looks out for what is important to me.

[The trustee] will go out of [the trustee's] way to help me.

[The trustee] has a strong sense of justice.

I never have to wonder whether [the trustee] will stick to [the trustee's] word.

[The trustee] tries hard to be fair in dealing with others.

[The trustee's] actions and behaviors are not very consistent.

I like [the trustee's] values.

Sound principles seem to guide [the trustee's] behavior.
Competence, perceived expertise

Loyalty, openness, caring, receptivity availability

Fairness, consistency, promise fulfillment, reliability, value congruence, discreetness 
teristics of the trustee, thereby assessing ability, integrity, and benevolence in addition to trust (e.g., Burgoon \& Hale, 1987; Cook \& Wall, 1980, Management subscale; Cummings \& Bromiley, 1996; Gabarro \& Athos, 1976; McAllister, 1995; Mishra \& Mishra, 1994). These measures were classified by Dirks and Ferrin (2002) as cognitive trust measures but had to be omitted from our trust analyses so that linkages between ability, benevolence, integrity, and trust could be tested cleanly (though we did include results for other relevant relationships from these articles). Other studies have used willingness-to-be-vulnerable measures with exemplar items like "I would be comfortable giving top management a task or problem which was critical to me, even if I could not monitor their actions" (Mayer \& Davis, 1999, taken from Schoorman et al., 1996; see also Davis et al., 2000; Mayer \& Gavin, 2005; Moorman, Zaltman, \& Deshpande, 1992). Still other studies have used direct measures with exemplar items like "How much trust do you place in your superiors?" (Earley, 1986; see also Ball et al., 1993; Brockner et al., 1997; Driscoll, 1978; Hammer \& Berman, 1981; Kirkpatrick \& Locke, 1996). Finally, some studies have used measures that could not be categorized into any of the three types because they blended item styles, whereas other studies have used multiple trust scales. In the case of multiple scales, one composite was formed for the overall analysis and the multiple scales were included separately in the various breakdowns used to compare results across measure types.

Variables were coded as risk taking if they referred to a specific choice that created a behavioral manifestation of the willingness to be vulnerable (Mayer et al., 1995; Ross \& LaCroix, 1996). Specific variables that were grouped into this coding category included the decision to delegate an important task, the choice to share information openly, the decision to avoid monitoring, the rejection of safeguards, and the choice to defer to a trustee.

With respect to job performance, task performance variables included objective indices of the fulfillment of job duties, along with both supervisory and self-ratings. The citizenship behavior variables included self-reports and reports by others of specific citizenship behaviors (e.g., altruism-helping, conscientiousnesscompliance, sportsmanship, civic virtue, courtesy, voice) and more general scales that tap a variety of behaviors (e.g., overall organizational citizenship behavior, or OCB, OCB-individual, OCBorganizational; e.g., K. Lee \& Allen, 2002; Podsakoff, MacKenzie, Moorman, \& Fetter, 1990; Van Dyne \& LePine, 1998; L. J. Williams \& Anderson, 1991). The counterproductive behavior variables included self-reports and reports by others of specific counterproductive behaviors (e.g., disciplinary actions, making of threats, disregard of safety procedures, tardiness, absenteeism) or more general scales that tap a variety of behaviors (e.g., Bennett \& Robinson, 2000; Lehman \& Simpson, 1992; Robinson \& O'LearyKelly, 1998).

We also coded variables that indicate the existence of a social exchange relationship in order to explore nontrust mediators of trustworthiness and trust propensity effects. As expected, our review indicated that constructs such as felt obligation and psychological contract fulfillment were not included in trust studies with enough frequency to be included in our meta-analyses. Affective commitment was examined with enough frequency, with the most common measures including Mowday, Steers, and Porter (1979) and Allen and Meyer (1990).

\section{Meta-Analytic Calculations}

We followed Hunter and Schmidt's (2004) guidelines for metaanalysis. Our meta-analytic results include a weighted mean estimate of the study correlations $(r)$, calculated by weighing each study's correlation by its sample size. The statistical significance of those correlations is judged using a 95\% confidence interval constructed around the point estimate (Whitener, 1990). We also report the value for those correlations after correcting for unreliability $\left(r_{\mathrm{c}}\right)$. Those corrections were performed using the reliability information provided in each article. For studies that did not report reliability information, we used the weighted mean reliability obtained from those studies that did report data for that variable.

In addition to providing calculations of uncorrected and corrected weighted mean correlations, meta-analysis can provide an estimate of the variability in the correlations. Our results include the standard deviation of the corrected meta-analytic correlation $\left(S D r_{\mathrm{c}}\right)$, which provides an index of the variation in study results for a given relationship. We also report the percentage of variance explained by artifacts $\left(V_{\text {art }}\right)$, which captures the extent to which variation in study results is caused by sampling error, unreliability, and other study artifacts. In cases in which the variance explained by artifacts is low, Hunter and Schmidt (2004) argued that moderator variables must be responsible for the variation in effect sizes across studies. More specifically, Hunter and Schmidt suggested that moderators are likely present if study artifacts fail to account for $75 \%$ of the variance in the meta-analytic correlations.

\section{Results}

\section{Meta-Analytic Summary of Trust Antecedents and Consequences}

Table 2 presents the meta-analytic results for the relationships between trust and its antecedents and consequences. With respect to the antecedents, ability $\left(r_{\mathrm{c}}=.67\right)$, benevolence $\left(r_{\mathrm{c}}=.63\right)$, and integrity $\left(r_{\mathrm{c}}=.62\right)$ were all strongly related to trust levels with cumulative number of subjects ranging from 3,326 to 7,284 . In contrast, trust propensity $\left(r_{\mathrm{c}}=.27\right)$ exhibited a more moderate relationship with a cumulative number of subjects of 1,514 . The $95 \%$ confidence intervals excluded zero for all four relationships. With respect to the consequences, trust was moderately to strongly related to risk taking $\left(r_{\mathrm{c}}=.42, N=1,384\right)$. Trust also was moderately related to all three job performance dimensions: task performance $\left(r_{\mathrm{c}}=.33, N=4,882\right)$, citizenship behavior $\left(r_{\mathrm{c}}=.27\right.$, $N=4,050)$, and counterproductive behavior $\left(r_{\mathrm{c}}=-.33, N=\right.$ $2,088)$. Note that objective measures of task performance $\left(r_{\mathrm{c}}=\right.$ $.31, N=1,068)$ yielded similar results to supervisory ratings of performance $\left(r_{\mathrm{c}}=.30, N=1,744\right)$ and self-ratings of performance $\left(r_{\mathrm{c}}=.36, N=2,070\right)$. Other-rated versus self-rated assessment also had little effect on the citizenship behavior results $\left(r_{\mathrm{c}}=.23\right.$, $N=2,002$ for other rated; $r_{\mathrm{c}}=.31, N=2,048$ for self-rated) and the counterproductive behavior results $\left(r_{\mathrm{c}}=-.29, N=842\right.$ for other rated; $r_{\mathrm{c}}=-.35, N=1,353$ for self-rated).

Table 3 summarizes how the relationships between trust and its antecedents and consequences vary by type of measure. The breakdowns suggest that the type of trust measure had little influence on the magnitude of the trust relationships, as the $95 \%$ confidence intervals overlapped in most cases. The exception was for direct 
Table 2

Meta-Analytic Summary of Trust Antecedents and Consequences

\begin{tabular}{|c|c|c|c|c|c|c|c|}
\hline Variable & $r$ & $95 \% \mathrm{CI}$ & $r_{\mathrm{c}}$ & $S D r_{\mathrm{c}}$ & $k$ & $N$ & $V_{\text {art }}(\%)$ \\
\hline \multicolumn{8}{|l|}{ Trust antecedents } \\
\hline Ability & .55 & $.51, .59$ & .67 & .19 & 18 & 3,885 & 9.7 \\
\hline Benevolence & .52 & $.47, .56$ & .63 & .20 & 20 & 3,326 & 11.9 \\
\hline Integrity & .53 & $.48, .58$ & .62 & .30 & 35 & 7,284 & 3.9 \\
\hline Trust propensity & .20 & $.14, .25$ & .27 & .14 & 10 & 1,514 & 58.7 \\
\hline \multicolumn{8}{|l|}{ Trust consequences } \\
\hline Risk-taking behaviors & .34 & $.28, .39$ & .42 & .22 & 13 & 1,384 & 25.0 \\
\hline Task performance & .26 & $.21, .31$ & .33 & .28 & 27 & 4,882 & 8.8 \\
\hline Citizenship behavior & .22 & $.19, .25$ & .27 & .14 & 19 & 4,050 & 38.6 \\
\hline Counterproductive behavior & -.26 & $-.30,-.22$ & -.33 & .08 & 10 & 2,088 & 92.7 \\
\hline
\end{tabular}

Note. $\quad r=$ uncorrected meta-analytic correlation; $\mathrm{CI}=$ confidence interval; $r_{\mathrm{c}}=$ corrected meta-analytic correlation; SD $r_{\mathrm{c}}=$ standard deviation of corrected meta-analytic correlation; $k=$ number of independent samples; $N=$ cumulative sample size; $V_{\text {art }}=$ percentage of variance in $r_{\mathrm{c}}$ explained by study artifacts.

measures, where relationships with benevolence were somewhat stronger and relationships with integrity were somewhat weaker.

Table 4 summarizes how the relationships between trust and its antecedents and consequences vary by trust referent. The breakdowns suggest that trust referent had little influence on the magnitude of the trust relationships, as the $95 \%$ confidence intervals overlapped in most cases. The exception was for the relationship between integrity and trust, where leader referents resulted in stronger correlations than coworker referents.

\section{Tests of Hypotheses}

Hypotheses 1a-c predicted that ability, benevolence, and integrity each have unique relationships with trust, controlling for one another. Meta-analytic structural equation modeling was used to test this hypothesis given that appropriate testing involves regression weights rather than zero-order correlations (Viswesvaran \& Ones, 1995). We first constructed the meta-analytic correlation matrix shown in Table 5. Because the two moderators we examined, type of measure and trust referent, did not significantly impact the trust correlations, we used the overall correlations in constructing Table 5. We then entered that meta-analytic correlation matrix into a structural equation modeling analysis using LISREL (Version 8.52; Jöreskog \& Sörbom, 1996). Given that the sample sizes differed across the various cells of the matrix, we used the harmonic mean sample size to compute standard errors (Viswesvaran \& Ones, 1995). The harmonic mean is calculated by the formula $\left[k /\left(1 / N_{1}+1 / N_{2}+\cdots+1 / N_{k}\right)\right]$, where $N$ refers to sample size and $k$ refers to the total number of samples. Use of the harmonic mean results in more conservative estimates, as less weight is given to large samples. The left side of Figure 1 reveals the results for Hypotheses 1a-c. All three coefficients were significant, supporting the hypotheses, with the ability relationship $(\beta=.39)$ and benevolence relationship $(\beta=.26)$ moderate in magnitude and the integrity relationship $(\beta=.15)$ weaker in magnitude.

Hypothesis 2 predicted that trust propensity is positively related to trust, controlling for ability, benevolence, and integrity. The left side of Figure 1 also reveals the result for this hypothesis. In support of the hypothesis, trust propensity remained a significant predictor of trust even when the trustworthiness forms were con- sidered simultaneously. However, the magnitude of the relationship was relatively weak $(\beta=.12)$.

Hypotheses $3 \mathrm{a}-\mathrm{c}$ predicted that the relationships between ability, benevolence, integrity, and the outcomes are partially mediated by trust. Hypothesis 4 made the same partial mediation prediction for trust propensity. In testing these hypotheses, we compared the fit of a full mediation model with a partial mediation model. The full mediation model is shown in Figure 1, with the antecedent relationships reviewed in the prior paragraphs supplemented by the outcome relationships from Table 2 . In testing the fit of the model in Figure 1, we allowed the error terms for task performance, citizenship behavior, and counterproductive behavior to covary in order to reflect their common core of job performance (Rotundo \& Sackett, 2002). The results revealed an acceptable level of fit for the full mediation structure, $\chi^{2}(19, N=1,204)=306.15, p<$ $.001 ; \mathrm{CFI}=.95 ; \mathrm{SRMR}=.07$. Acceptable model fit typically is inferred when CFI is above .90 and SRMR is below .10 (Kline, 2005).

The partial mediation model is shown in Figure 2, which adds direct paths between the four trust antecedents and the four outcomes. The error terms for task performance, citizenship behavior, and counterproductive behavior again were allowed to covary. The results revealed a better fit for the partial mediation structure, $\chi^{2}(3$, $N=1,204)=120.60, p<.001 ; \mathrm{CFI}=.98 ; \mathrm{SRMR}=.05$. The significance of the improvement in model fit can be judged using a chi-square difference test, and the difference in chi-square $(306.15-120.60=185.55)$ was statistically significant with $(19$ $-3=16$ ) degrees of freedom $(p<.001)$. This improvement in fit supports the view that trust is only a partial mediator of the relationships between the trust antecedents and the outcomes.

Support for Hypotheses 3 and 4 also can be seen when examining the path coefficients in Figure 2. When risk taking was regressed on trust and its antecedents simultaneously, trust remained a significant predictor $(\beta=.25)$. However, ability $(\beta=$ $.12)$ and integrity $(\beta=.15)$ had significant relationships independent of trust, illustrating that trust did not completely mediate their effects. A similar pattern occurred for task performance. When task performance was regressed on trust and its antecedents simultaneously, trust remained a significant predictor $(\beta=.38)$. However, trust propensity $(\beta=.07)$ and integrity $(\beta=-.12)$ also had 
Table 3

Type of Trust Measure as a Moderator of Trust Relationships

\begin{tabular}{|c|c|c|c|c|c|c|c|}
\hline Trust measure type & $r$ & $95 \% \mathrm{CI}$ & $r_{\mathrm{c}}$ & $S D r_{\mathrm{c}}$ & $k$ & $N$ & $V_{\text {art }}(\%)$ \\
\hline \multicolumn{8}{|c|}{ Trust antecedents } \\
\hline \multicolumn{8}{|l|}{ Ability } \\
\hline Positive expectations & .48 & $.41, .55$ & .59 & .27 & 7 & 918 & 9.4 \\
\hline Willingness to be vulnerable & .56 & $.52, .60$ & .69 & .17 & 10 & 2,830 & 8.8 \\
\hline Direct & .55 & $.49, .61$ & .65 & .17 & 5 & 722 & 17.5 \\
\hline \multicolumn{8}{|l|}{ Benevolence } \\
\hline Positive expectations & .49 & $.44, .53$ & .59 & .15 & 11 & 1,699 & 26.0 \\
\hline Willingness to be vulnerable & .54 & $.48, .60$ & .67 & .27 & 7 & 1,516 & 5.0 \\
\hline \multirow{2}{*}{\multicolumn{8}{|c|}{ Integrity }} \\
\hline & & & & & & & \\
\hline Positive expectations & .62 & $.59, .65$ & .69 & .14 & 18 & 3,501 & 14.0 \\
\hline Willingness to be vulnerable & .62 & $.58, .66$ & .76 & .17 & 9 & 2,030 & 9.4 \\
\hline Direct & .51 & $.46, .56$ & .62 & .24 & 10 & 1,691 & 8.5 \\
\hline \multicolumn{8}{|l|}{ Trust propensity } \\
\hline Positive expectations & .20 & $.11, .28$ & .26 & .11 & 4 & 596 & 94.0 \\
\hline Willingness to be vulnerable & 18 & $.10, .26$ & .25 & .09 & 4 & 673 & 100.0 \\
\hline Direct & .16 & $.09, .24$ & .22 & .13 & 5 & 699 & 86.2 \\
\hline \multicolumn{8}{|c|}{ Trust consequences } \\
\hline \multicolumn{8}{|l|}{ Risk-taking behaviors } \\
\hline Positive expectations & .30 & $.21, .38$ & .39 & .13 & 4 & 567 & 60.0 \\
\hline Willingness to be vulnerable & .32 & $.20, .43$ & .39 & .25 & 2 & 369 & 12.0 \\
\hline Direct & .15 & $.05, .26$ & .20 & .07 & 3 & 409 & 100.0 \\
\hline \multicolumn{8}{|l|}{ Task performance } \\
\hline Positive expectations & .22 & $.16, .28$ & .25 & .20 & 13 & 1,645 & 27.4 \\
\hline Willingness to be vulnerable & .21 & $.15, .27$ & .26 & .15 & 7 & 1,199 & 35.4 \\
\hline Direct & .17 & $.10, .24$ & .20 & .21 & 6 & 917 & 20.5 \\
\hline \multicolumn{8}{|l|}{ Citizenship behavior } \\
\hline Positive expectations & .23 & $.18, .27$ & .28 & .15 & 14 & 2,335 & 37.0 \\
\hline Willingness to be vulnerable & .19 & $.14, .24$ & .24 & .02 & 5 & 1,572 & 100.0 \\
\hline Direct & .23 & $.13, .34$ & .28 & .22 & 3 & 469 & 17.0 \\
\hline \multicolumn{8}{|l|}{ Counterproductive behavior } \\
\hline Positive expectations & -.24 & $-.32,-.16$ & -.27 & .16 & 5 & 624 & 39.9 \\
\hline Willingness to be vulnerable & -.18 & $-.11,-.20$ & -.26 & .10 & 4 & 623 & 100.0 \\
\hline Direct & -.22 & $-.32,-.13$ & -.26 & .11 & 4 & 487 & 89.7 \\
\hline
\end{tabular}

Note. $\quad r=$ uncorrected meta-analytic correlation; $\mathrm{CI}=$ confidence interval; $r_{\mathrm{c}}=$ corrected meta-analytic correlation; SDr $r_{\mathrm{c}}=$ standard deviation of corrected meta-analytic correlation; $k=$ number of independent samples; $N=$ cumulative sample size; $V_{\text {art }}=$ percentage of variance in $r_{\mathrm{c}}$ explained by study artifacts.

smaller, unique relationships (note that the negative coefficient for integrity may be an artifact of the high multicollinearity among the trustworthiness facets). A similar pattern also occurred for counterproductive behavior. When counterproductive behavior was regressed on trust and its antecedents simultaneously, trust remained a significant predictor $(\beta=-.25)$. However, trust propensity $(\beta=$ $-.19)$, benevolence $(\beta=-.10)$, and ability $(\beta=.11)$ also had smaller, unique relationships (note again that the positive coefficient for ability may be an artifact of high multicollinearity). Taken together, these results reveal that trust mediates much, but not all, of the relationships between the trust antecedents and those three outcomes.

A different pattern of results is observed for citizenship behavior, however. When citizenship behavior was regressed on trust and its antecedents simultaneously, trust remained a significant predictor $(\beta=.11)$. However, ability $(\beta=.18)$ and trust propensity $(\beta=.10)$ also had significant, unique relationships with citizenship, and the magnitude of those relationships was similar to (or slightly stronger than) the trust effect. This result suggests that trust only mediates a fraction of the relationships between ability, trust propensity, and citizenship behavior. In sum, our tests of Hypotheses 3 and 4 suggest that trust does mediate the relationships between trustworthiness, trust propensity, and the outcomes, but the mediation is only partial, as many of the antecedents possessed unique relationships with the outcomes.

Hypotheses 5 and 6 entailed an attempt to explain that partial mediation by examining affective commitment as another mediator of trustworthiness and trust propensity effects. Recall that trust was expected to mediate the effects of those antecedents because it serves as an indicator that a social exchange relationship has developed. However, trust is not the only construct that indicates a social exchange relationship, as affective commitment also serves as evidence of such a relationship. Table 5 includes the correlations between affective commitment and the other variables in our models. Figure 3 depicts affective commitment as an additional mediator for trustworthiness and trust propensity effects. We allowed the errors to covary for trust and affective commitment to reflect a reciprocal association among the two social exchange 
Table 4

Trust Referent as a Moderator of Trust Relationships

\begin{tabular}{|c|c|c|c|c|c|c|c|}
\hline Trust referent & $r$ & $95 \% \mathrm{CI}$ & $r_{\mathrm{c}}$ & $S D r_{\mathrm{c}}$ & $k$ & $N$ & $V_{\text {art }}(\%)$ \\
\hline \multicolumn{8}{|c|}{ Trust antecedents } \\
\hline \multicolumn{8}{|l|}{ Ability } \\
\hline Coworker-based referent & .52 & $.46, .58$ & .62 & .24 & 5 & 1,299 & 5.7 \\
\hline Leader-based referent & .55 & $.51, .59$ & .68 & .17 & 11 & 2,122 & 14.5 \\
\hline \multicolumn{8}{|l|}{ Benevolence } \\
\hline Coworker-based referent & .41 & $.33, .50$ & .51 & .17 & 4 & 501 & 28.9 \\
\hline Leader-based referent & .51 & $.46, .55$ & .63 & .20 & 15 & 2,566 & 12.7 \\
\hline \multicolumn{8}{|l|}{ Integrity } \\
\hline Coworker-based referent & .11 & $.01, .22$ & .13 & .48 & 4 & 897 & 2.8 \\
\hline Leader-based referent & .58 & $.54, .61$ & .67 & .18 & 30 & 6,128 & 9.5 \\
\hline \multicolumn{8}{|l|}{ Trust propensity } \\
\hline Coworker-based referent & .28 & $.20, .36$ & .37 & .13 & 4 & 622 & 56.8 \\
\hline Leader-based referent & .15 & $.07, .23$ & .21 & .11 & 5 & 633 & 100.0 \\
\hline
\end{tabular}

Trust consequences

\begin{tabular}{|c|c|c|c|c|c|c|c|}
\hline \multicolumn{8}{|l|}{ Risk-taking behaviors } \\
\hline Coworker-based referent & .32 & $.25, .40$ & .39 & .20 & 6 & 730 & 25.5 \\
\hline Leader-based referent & .28 & $.17, .39$ & .37 & .30 & 6 & 395 & 26.8 \\
\hline \multicolumn{8}{|l|}{ Task performance } \\
\hline Coworker-based referent & .30 & $.24, .36$ & .39 & .31 & 10 & 2,327 & 5.4 \\
\hline Leader-based referent & .22 & $.17, .27$ & .26 & .09 & 16 & 2,495 & 16.5 \\
\hline \multicolumn{8}{|l|}{ Citizenship behavior } \\
\hline Coworker-based referent & .23 & $.12, .33$ & .27 & .20 & 4 & 446 & 33.1 \\
\hline Leader-based referent & .22 & $.19, .26$ & .27 & .12 & 12 & 3,002 & 40.2 \\
\hline \multicolumn{8}{|l|}{ Counterproductive behavior } \\
\hline Coworker-based referent & -.24 & $-.31,-.17$ & -.33 & .09 & 3 & 838 & 63.5 \\
\hline Leader-based referent & -.26 & $-.31,-.21$ & -.32 & .09 & 8 & 1,357 & 100.0 \\
\hline
\end{tabular}

Note. $\quad r=$ uncorrected meta-analytic correlation; $\mathrm{CI}=$ confidence interval; $r_{\mathrm{c}}=$ corrected meta-analytic correlation; $S D r_{\mathrm{c}}=$ standard deviation of corrected meta-analytic correlation; $k=$ number of independent samples; $N=$ cumulative sample size; $V_{\text {art }}=$ percentage of variance in $r_{\mathrm{c}}$ explained by study artifacts.

indicators. The results revealed an adequate fit to the data, $\chi^{2}(3, N$ $=1,319)=154.59, p<.001 ; \mathrm{CFI}=.98 ; \mathrm{SRMR}=.05$, and Figure 3 shows that ability $(\beta=.22)$, benevolence $(\beta=.20)$, and integrity $(\beta=.22)$ were significantly and uniquely related to affective commitment, though trust propensity did not yield as large of an effect $(\beta=.05)$. Affective commitment also was uniquely related to the outcomes, particularly citizenship behavior $(\beta=.18)$ and counterproductive behavior $(\beta=-.39)$. However, many of the direct effects of trustworthiness on the four outcomes remained significant, even with affective commitment as an additional mediator. The exception was the relationship between benevolence and counterproductive behavior, which became nonsignificant with affective commitment controlled.

\section{Discussion}

Mayer et al.'s (1995) integrative model and Rousseau et al.'s (1998) cross-discipline review helped clarify the conceptual distinctions among trust, trustworthiness, and trust propensity. Mayer et al. also introduced a three-factor conceptualization of trustworthiness and cast trust as the most proximal predictor of risk taking and other behavioral outcomes. Although the conceptual contributions of these articles are notable, a number of critical questions remain a decade later. These questions center on the unique effects of ability, benevolence, and integrity on trust; the mediating role of trust in explaining the relationships between trustworthiness, trust propensity, and behavioral outcomes; and the effects of trust measurement and trust referent on relationships with antecedents and consequences. Although the trust literature previously has been subject to a meta-analysis, Dirks and Ferrin's (2002) review did not speak to these specific questions because their conceptualization of trust was an aggregate of trust and trustworthiness in a Mayer et al. sense. In addition, their review focused specifically on leader-based referents and did not include variables such as ability and risk taking. Our meta-analyses therefore complement Dirks and Ferrin's (2002) review, and our results offer a number of theoretical, measurement, and practical implications.

\section{Theoretical Implications}

Lewis and Weigert (1985) suggested that trust is based on "“good reasons' constituting evidence of trustworthiness" (p. 970). Although Mayer et al. (1995) defined those "good reasons" in terms of ability, benevolence, and integrity, some studies have failed to demonstrate significant, unique effects for all three dimensions when predicting trust (Jarvenpaa et al., 1998; Mayer \& Gavin, 2005), and the trustworthiness dimensions often are highly correlated. Moreover, some conceptualizations of trustworthiness combine benevolence and integrity into a single character variable (Gabarro, 1978), suggesting that those two dimensions might be redundant with each other. Our results support the importance of all three trustworthiness dimensions, as all three had significant, 
unique relationships with trust. One explanation for those unique relationships may be that the trustworthiness dimensions reflect both cognition-based and affect-based sources of trust (Flores \& Solomon, 1998; Lewicki \& Bunker, 1996; Lewis \& Weigert, 1985; McAllister, 1995, 1997; Rousseau et al., 1998; Shapiro et al., 1992). For example, a cognitive calculation of the skills, capabilities, values, and principles of the trustee (in the forms of ability and integrity) may be supplemented by a more affective acknowledgment of the mutual concern inherent in the relationship (in the form of benevolence).

Of course, trust often requires a leap beyond the expectations that ability, benevolence, and integrity can inspire (Lewis \& Weigert, 1985). Trust propensity may drive that leap (Mayer et al., 1995; Rosenberg, 1956; Rotter, 1967; Stack, 1978), as our results showed that propensity was related to trust on both a zero-order basis and when trustworthiness was considered simultaneously. It also is worth noting that propensity was significantly related to all three trustworthiness facets. If propensity were to be viewed as an antecedent of trustworthiness perceptions (by changing the curved arrows in the figures into direct paths to ability, benevolence, and integrity), it would have significant indirect effects on trust to go along with its significant direct effect. That sort of structure is consistent with some models in the literature (Kee \& Knox, 1970; McKnight et al., 1998; Ross \& LaCroix, 1996) and matches Govier's (1994) view that "observations are theory-laden," with trusting parties perceiving more good reasons to trust (p. 244).

In addition to exploring trust antecedents, our study examined the specific behaviors that trust can be used to predict. Most important, we tested Mayer et al.'s (1995) fundamental assumption that trust fosters risk taking-that an intention to accept vulnerability actually results in a decision to become vulnerable (see also Kee \& Knox, 1970; Ross \& LaCroix, 1996). Our results revealed moderately strong relationships between trust and risk taking. Moreover, our results revealed moderately strong relationships between trust and the three facets of job performance, as individuals who are willing to trust others tend to engage in better task performance, perform more citizenship behaviors, and commit fewer counterproductive behaviors. Taken together, these sorts of results reinforce the view that trust is a vital component of effective working relationships (Lind, 2001; Tyler \& Lind, 1992).

Our results also showed that trust benefits relationships with both leaders and coworkers. On the one hand, Mayer et al.'s (1995) integrative model de-emphasized the importance of different kinds of trust referents, focusing instead on any identifiable party who acts with volition toward the trustor. On the other hand, scholars have treated trust in leadership as a distinct phenomenon, as evidenced by Dirks and Ferrin's (2002) exclusive focus on trust in leadership. Our results showed that, in general, the relationships between trust and its antecedents and consequences did not vary across leader-based and coworker-based referents. The one exception was the relationship between integrity and trust, which was significantly stronger for leader-based referents. It may be that issues of fairness, consistency, promise fulfillment, and so forth are more salient in relationships with an obvious power differential.

Finally, our study explored the question "Are trustworthiness and trust propensity important only because they inspire trust?" Mayer et al. (1995) suggested that trust completely mediates the relationships between trustworthiness or trust propensity and out- 


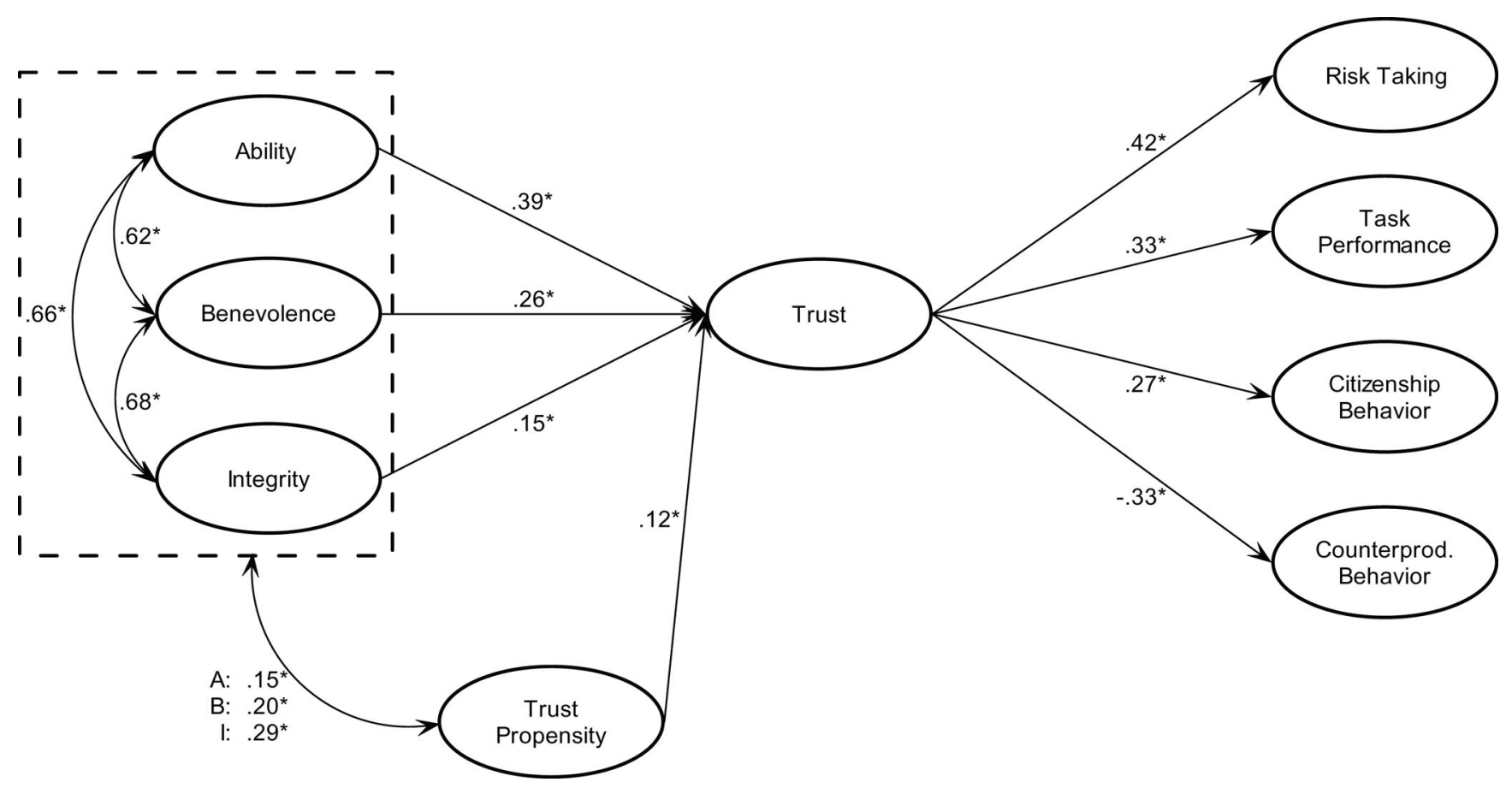

Figure 1. Full mediation model. $N=1,204$. Counterprod. = counterproductive; $\mathrm{A}=$ ability relationship; $\mathrm{B}=$ benevolence relationship; I = integrity relationship. ${ }^{*} p<.05$.

comes (see also Kee \& Knox, 1970; Ross \& LaCroix, 1996; M. Williams, 2001). Our results suggest that trustworthiness and trust propensity may be important even aside from their trust-fostering role, in two respects. First, ability, benevolence, integrity, and trust propensity had significant, unique relationships with behavioral outcomes even when trust was considered simultaneously. For example, integrity had incremental effects on risk taking, and benevolence had incremental effects on counterproductive behaviors. Ability had incremental effects on both risk taking and citizenship behavior, and trust propensity had incremental effects on both citizenship behavior and counterproductive behavior.

Second, ability, benevolence, and integrity were significant predictors of affective commitment, not just trust. We had reasoned that trustworthiness and trust propensity might have independent relationships with the outcomes when controlling for trust because they can engender a social exchange relationship. Trust can act as a partial indicator of that social exchange relationship (Aryee et al., 2002; Konovsky \& Pugh, 1994; Shore et al., 2006), but other constructs-like affective commitment - can serve a similar function (Mowday et al., 1982; Shore et al., 2006). Our results showed that affective commitment was a significant predictor of citizenship behavior and counterproductive behavior when controlling for trust. From this perspective, trustworthiness may have a dual importance-predicting behaviors through the mechanisms of both trust and affective commitment.

Although affective commitment provided an additional mediator for the effects of trustworthiness and trust propensity, it must be noted that the trust antecedents had incremental effects on the outcomes even when both mediators were controlled. We suspect these remaining direct effects point to the importance of still other social exchange indicators, such as felt obligation (Eisenberger et al., 2001) and psychological contract fulfillment (Aselage \& Eisenberger, 2003; Robinson \& Rousseau, 1994; Turnley et al., 2003). Unfortunately, these indicators have not been included in trust studies with enough frequency to be included in our analyses, though both offer useful directions for future research. Alternatively, it may be that demonstrating complete mediation for trustworthiness and trust propensity requires a more comprehensive or direct approach to operationalizing the social exchange phenomenon. For example, Shore et al. (2006) validated a scale that reflects multiple facets of social exchange relationships, including the trust within the relationship, the investment between the two parties, the duration of the exchange, and the socioemotional (as opposed to financial) focus of the exchange. It may be that this sort of measure would fully mediate trustworthiness and trust propensity effects because the full spectrum of exchange concepts is being captured.

\section{Measurement Implications}

In addition to the theoretical implications we have described, our article has a number of implications for measurement within the trust literature. For example, our results revealed high intercorrelations between the ability, benevolence, and integrity dimensions. Although the three dimensions still had significant, unique relationships with trust and affective commitment, such high intercorrelations could lead to unstable regression weights, particularly in primary studies with modest sample sizes. Indeed, we suspect that the multicollinearity among the ability, benevolence, and integrity dimensions was responsible for the small regression weights in Figures 2 and 3 that were opposite in sign from the zero-order correlations. Mayer et al. (1995) provided compelling 


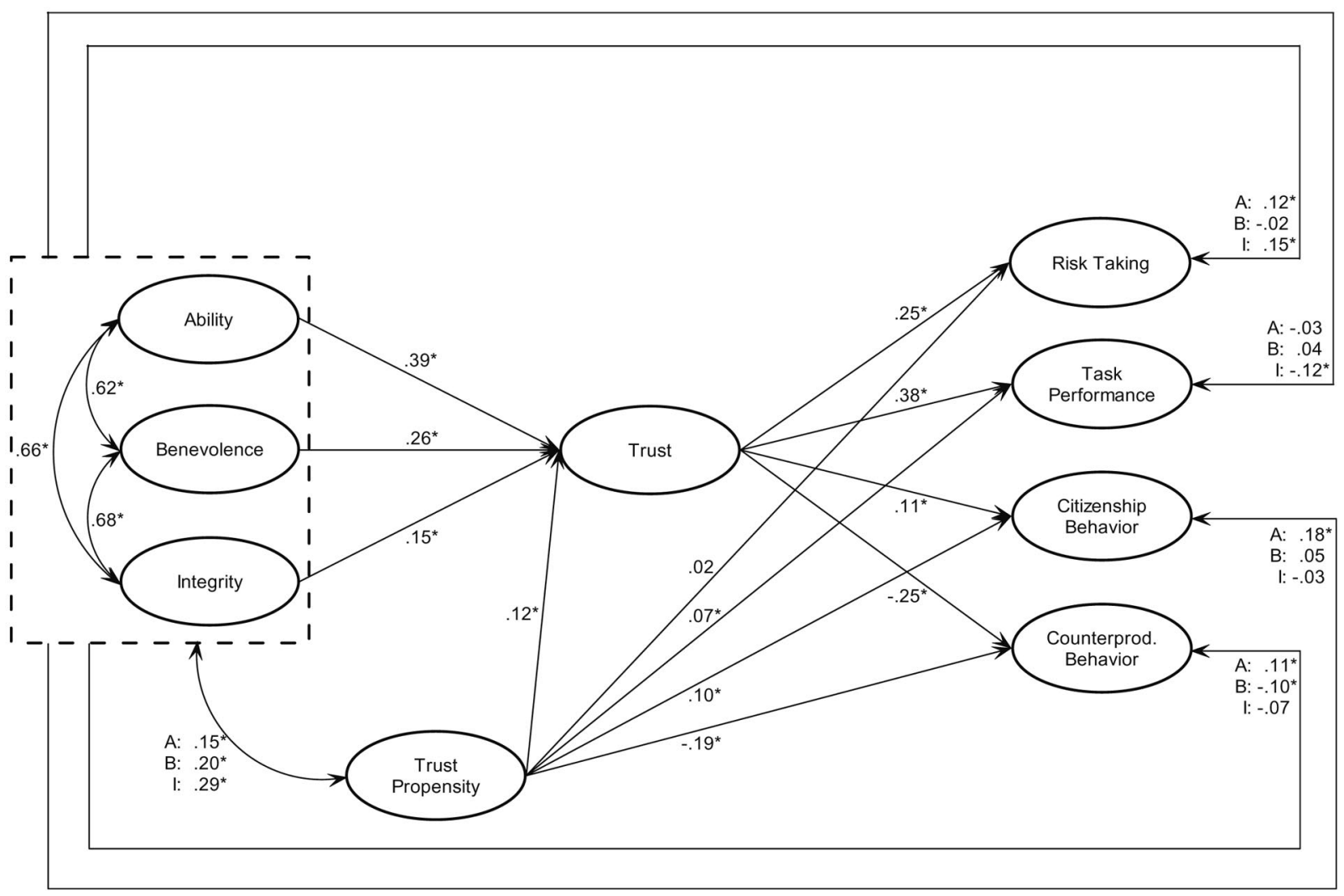

Figure 2. Partial mediation model. $N=1,204 . \mathrm{A}=$ ability relationship; $\mathrm{B}=$ benevolence relationship; $\mathrm{I}=$ integrity relationship; Counterprod. $=$ counterproductive. ${ }^{*} p<.05$.

conceptual evidence for the distinctions among the three trustworthiness factors. It may be that those conceptual distinctions are more difficult to maintain in the minds of survey respondents who fill out scales like Mayer and Davis's (1999). Alternatively, it may be that there is overlap between the trustworthiness dimensions that could be clarified further at both a conceptual and operational level. For example, demonstrating caring and concern is a facet of benevolence, whereas a strong sense of justice is a facet of integrity (Mayer \& Davis, 1999; Mayer et al., 1995). However, scholars in the organizational justice literature view caring and concern as a facet of "interactional justice" (Bies \& Moag, 1986), suggesting a blurring of the benevolence-integrity boundary.

Other measurement implications can be derived from our analyses of trust measurement approach as a moderator of trust relationships. Specifically, our results showed that the relationships between trust and its antecedents and consequences did not vary significantly across measures based on the positive expectations or willingness-to-be-vulnerable components of trust definitions (Mayer et al., 1995; Rousseau et al., 1998) or across direct measures that explicitly use the word trust. The fact that measurement approach did not appear to be a significant moderator suggests that it may not matter in what sense one trusts. There are two reasons why that contention should be viewed with caution, however. First, we had to exclude some commonly used trust measures from our review because they explicitly measured positive expectations in reference to ability, benevolence, or integrity rather than the ac- tions of the trustee (e.g., Burgoon \& Hale, 1987; Cook \& Wall, 1980, Management subscale; Cummings \& Bromiley, 1996; Gabarro \& Athos, 1976; McAllister, 1995; Mishra \& Mishra, 1994). Second, the most rigorous test of trust measurement effects would involve including positive expectations, willingness to be vulnerable, and direct measures in a single study to see how their zero-order and unique relationships differ from one another. Unfortunately, the inclusion of multiple types of scales in a single study remains extremely rare.

\section{Limitations}

This study has some limitations that should be noted. First, like any meta-analysis, it subsumes the limitations of the studies on which it is built. For example, many of the studies included in our review yielded correlations that could have been inflated by samesource bias, inflation that also would impact our meta-analytic correlations. Similarly, many of the studies included in our review used a cross-sectional correlational design, preventing us from establishing causal direction in our analyses. This limitation is particularly relevant to our mediation analyses, given that the term mediation presumes a specific causal direction (Stone-Romero \& Rosopa, 2004). Also, our analyses examined only the main effects of trustworthiness, trust propensity, and trust. Mayer et al.'s (1995) model argued that trust propensity could moderate the effects of trustworthiness on trust. Unfortunately, meta-analytic structural 


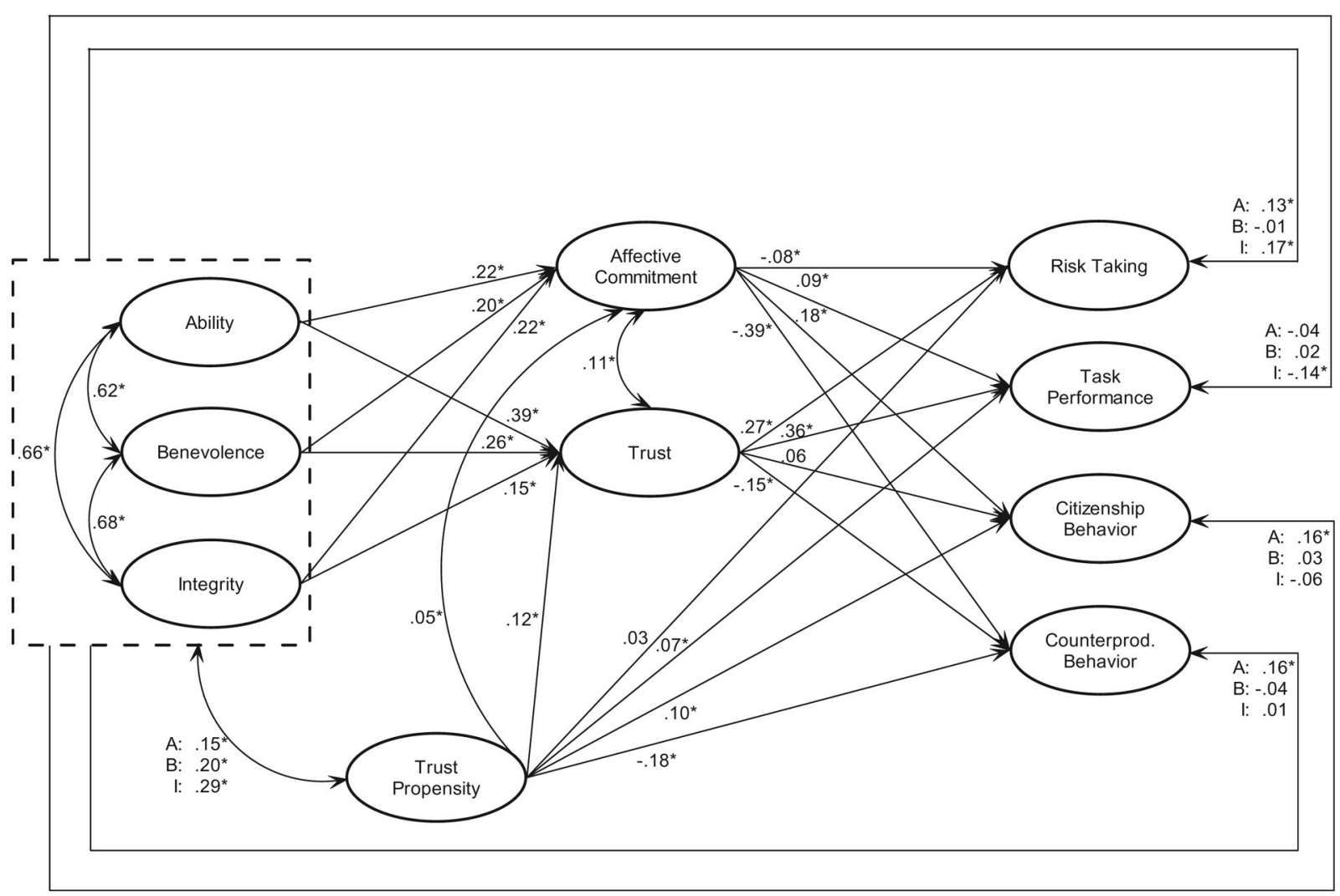

Figure 3. Partial mediation model with affective commitment. $\mathrm{A}=$ ability relationship; $\mathrm{B}=$ benevolence relationship; $\mathrm{I}=$ integrity relationship; Counterprod. $=$ counterproductive. $N=1,319 .{ }^{*} p<.05$.

equation modeling is ill suited to examining such effects because it requires the reporting of zero-order effect sizes in the studies. Authors would need to report the zero-order correlations with moderated regression product terms in order for interactive effects to be explored.

\section{Suggestions for Future Research}

Despite these limitations, our quantitative review offers a number of suggestions for future research. For example, trust scholars have neglected to examine whether the importance of the three trustworthiness facets varies across jobs. Ability may be a stronger predictor in jobs that require frequent learning or technical competence (Schmidt \& Hunter, 2000). Benevolence and integrity may be stronger predictors in jobs where task interdependence necessitates frequent interactions (Wageman, 2001). Although our review could not test those specific suggestions, we did explore breakdowns of the trustworthiness-trust relationships for the field studies included in our review using manufacturing, service, and managerial job categories. The number of studies in those breakdowns proved to be too small to draw any firm conclusions, but some differences do seem worthy of further investigation. For example, ability seemed to be a more significant predictor of trust in manufacturing jobs than in managerial jobs, with service jobs only appearing in a single study $(r=.64[.57, .70], k=2, N=415$ for manufacturing; $r=.41[.28, .54], k=3, N=284$ for managerial; $r=.56$ [.48, .64], $k=1, N=381$ for service).
Similarly, benevolence seemed to be a more significant predictor of trust in manufacturing and service jobs than in managerial jobs $(r=.62[.56, .68], k=3, N=493$ for manufacturing; $r=.29[.09$, $.49], k=2, N=175$ for managerial; $r=.46[.40, .52], k=3, N=$ 897 for service).

In contrast to the ability and benevolence results, integrity seemed to be a more significant predictor of trust in managerial and service jobs than in manufacturing jobs $(r=.30[.21, .29], k=$ $7, N=1,793$ for manufacturing; $r=.65[.49, .81], k=2, N=141$ for managerial; $r=.62[.57, .66], k=5, N=899$ for service). The result for managerial jobs complements our finding that the integrity-trust relationship was significantly stronger for leaderbased trust referents than for coworker-based trust referents (see Table 4). It seems that the qualities associated with integrity, such as reliability, promise fulfillment, and fairness, become even more important in cases in which authority dynamics are particularly salient. Lind (2001) argued that issues such as fairness and ethicality are especially critical in authority-based contexts because the risk of exploitation is apparent. Future research should attempt to replicate the integrity effects reported here while identifying the mechanisms that could explain such differences.

Other suggestions for future research center on how employees react to trust in multiple authorities. As Mayer and Gavin (2005) illustrated in their study of trust in plant managers and top management teams, employees trust multiple authorities at a given time. Dirks and Ferrin's (2002) review revealed that trust in one's 
direct leader had a stronger effect on task performance and citizenship behavior than trust in organizational leadership. Our results show a similar pattern for citizenship behavior, though the number of studies is too small to identify significant differences $(r=.24[.20, .28], k=10, N=2,651$ for direct leader; $r=.13$ $[.01, .25], k=2, N=351$ for organizational leadership). However, our breakdowns for task performance $(r=.19$ [.14, .25], $k=12$, $N=1,979$ for direct leader; $r=.31[.22, .41], k=4, N=516$ for organizational leadership), risk taking ( $r=.23$ [.06, .39], $k=4$, $N=222$ for direct leader; $r=.35[.15, .54], k=2, N=173$ for organizational leadership), and counterproductive behavior ( $r=$ $-.25[-.31,-.20], k=7, N=1,253$ for direct leader; $r=-.36$ $[-.87, .15], k=1, N=104$ for organizational leadership) revealed the opposite pattern, with trust in organizational leadership more strongly related to these outcomes, though the confidence intervals overlapped in all cases. Future research should continue to explore such differences while also examining the unique effects of multiple trust referents on employee reactions.

\section{Practical Implications}

Our article also offers a number of practical implications. First and foremost, our results underscore the practical benefits of fostering trust in the workplace. The relationship between trust and job performance was as strong as or stronger than relationships with other attitudes such as job satisfaction (Judge, Thoreson, Bono, \& Patton, 2001). Trust also predicted risk taking, which is vital in many jobs where formal or legalistic controls do not protect exchange partners (Hardin, 1996; Sitkin \& Roth, 1993). Trust also predicted counterproductive behaviors, which can prove quite costly to organizations even when the base rates for committing them remain low (Sackett \& DeVore, 2001). In addition, trust was positively correlated with affective commitment, a significant predictor of both absenteeism and turnover (Meyer, Stanley, Herscovitch, \& Topolnytsky, 2002).

Given the importance of trust to key organizational outcomes, our trustworthiness results can provide a guide for increasing trust in organizations. Ability, benevolence, and integrity provide three distinct avenues for fostering trust, as all three were highly correlated with trust and all three had significant, unique relationships with it. The ability results reinforce the importance of recruitment and selection strategies geared toward maximizing general abilities and training strategies targeted at building task-specific expertise (Arthur, Bennett, Edens, \& Bell, 2003; Rynes, 1991). With respect to benevolence and integrity, coworker-based relationships could benefit from building such content into team-building programs. Although the long-term benefits of such programs are open to debate (Salas, Rozell, Mullen, \& Driskell, 1999), their effectiveness may be enhanced if they are focused specifically on trustworthiness antecedents. Leader-based relationships potentially could benefit from incorporating trustworthiness drivers into leader training. Skarlicki and Latham (1996) demonstrated that leaders could be trained to act in a more fair and ethical manner. Training geared toward improving the facets of integrity could be particularly effective given the importance of integrity in leader-based relationships.

\section{References}

References marked with an asterisk indicate studies included in the meta-analysis

*Adams, E. F. (1978). A multivariate study of subordinate perceptions of and attitudes toward minority and majority managers. Journal of Applied Psychology, 63, 277-288.

*Albrecht, S. L. (2002). Perceptions of integrity, ability and trust in senior management as determinants of cynicism toward change. Public Administration \& Management, 7, 320-343.

Allen, N. J., \& Meyer, J. P. (1990). The measurement and antecedents of affective, continuance, and normative commitment to the organization. Journal of Occupational Psychology, 63, 1-18.

*Amason, A. C., \& Sapienza, H. J. (1997). The effects of top management team size and interaction norms on cognitive and affective conflict. Journal of Management, 23, 495-516.

*Ambrose, M. L., \& Schminke, M. (2003). Organization structure as a moderator of the relationship between procedural justice, interactional justice, perceived organizational support, and supervisory trust. Journal of Applied Psychology, 88, 295-305.

*Armstrong-Stassen, M. (1993). Production workers' reactions to a plant closing: The role of transfer, stress, and support. Anxiety, Stress, and Coping, 6, 201-214.

*Armstrong-Stassen, M. (2002). Designated redundant but escaping layoff: A special group of layoff survivors. Journal of Occupational and Organizational Psychology, 75, 1-13.

Arthur, W., Bennett, W., Edens, P. S., \& Bell, S. T. (2003). Effectiveness of training in organizations: A meta-analysis of design and evaluation features. Journal of Applied Psychology, 88, 234-245.

*Aryee, S., Budhwar, P. S., \& Chen, Z. X. (2002). Trust as a mediator of the relationship between organizational justice and work outcomes: Test of a social exchange model. Journal of Organizational Behavior, 23, 267-285.

Aselage, J., \& Eisenberger, R. (2003). Perceived organizational support and psychological contracts: A theoretical integration. Journal of Organizational Behavior, 24, 491-509.

*Ball, G. A., Trevino, L. K., \& Sims, H. P., Jr. (1993). Justice and organizational punishment: Attitudinal outcomes of disciplinary events. Social Justice Research, 6, 39-67.

Barber, B. (1983). The logic and limits of trust. New Brunswick, NJ: Rutgers University Press.

*Bass, B., \& Mitchell, C. W. (1976). Influences on the felt need for collective bargaining by business and science professionals. Journal of Applied Psychology, 61, 770-773.

Becker, L. C. (1996). Trust as noncognitive security about motives. Ethics, 107, 43-61.

Bennett, R. J., \& Robinson, S. L. (2000). Development of a measure of workplace deviance. Journal of Applied Psychology, 85, 349-360.

Bies, R. J., \& Moag, J. F. (1986). Interactional justice: Communication criteria of fairness. In R. J. Lewicki, B. H. Sheppard, \& M. H. Bazerman (Eds.), Research on negotiations in organizations (Vol. 1, pp. 43-55). Greenwich, CT: JAI Press.

Bigley, G. A., \& Pearce, J. L. (1998). Straining for shared meaning in organizational science: Problems of trust and distrust. Academy of Management Review, 23, 405-421.

Blau, P. M. (1964). Exchange and power in social life. New York: Wiley. Boon, S. D., \& Holmes, J. G. (1991). The dynamics of interpersonal trust: Resolving uncertainty in the face of risk. In R. A. Hinde \& J. Groebel (Eds.), Cooperation and prosocial behavior (pp. 190-211). Cambridge, England: Cambridge University Press.

Borman, W. C., \& Motowidlo, S. J. (1993). Expanding the criterion domain to include elements of contextual performance. In N. Schmitt, W. C. Borman, \& Associates (Eds.), Personnel selection in organizations (pp. 71-98). San Francisco: Jossey-Bass. 
*Brashear, T. G., Manolis, C., \& Brooks, C. M. (2005). The effects of control, trust, and justice on salesperson turnover. Journal of Business Research, 58, 241-249.

*Brockner, J., Siegel, P. A., Daly, J. P., Tyler, T., \& Martin, C. (1997). When trust matters: The moderating effect of outcome favorability. Administrative Science Quarterly, 42, 558-583.

*Brockner, J., Wiesenfeld, B. M., \& Martin, C. L. (1995). Decision frame, procedural justice, and survivors' reactions to job layoffs. Organizational Behavior and Human Decision Processes, 63, 59-68.

Burgoon, J. K., \& Hale, J. (1987). Validation and measurement of the fundamental themes of relational communication. Communication Monographs, 54, 19-41.

Burt, R. S. (1992). Structural holes: The social structure of competition. Cambridge, MA: Harvard University Press.

*Butler, J. K., Jr. (1991). Toward understanding and measuring conditions of trust: Evolution of a conditions of trust inventory. Journal of Management, 17, 643-663.

Butler, J. K., Jr., \& Cantrell, R. S. (1984). A behavioral decision theory approach to modeling dyadic trust in superiors and subordinates. Psychological Reports, 55, 19-28.

*Butler, J. K., Jr., Cantrell, R. S., \& Flick, R. J. (1999). Transformational leadership behaviors, upward trust, and satisfaction in self-managed work teams. Organization Development Journal, 17, 13-28.

Campbell, J. P. (1990). Modeling the performance prediction problem. In M. D. Dunnette \& L. M. Hough (Eds.), Handbook of industrial and organizational psychology (Vol. 1, pp. 687-732). Palo Alto, CA: Consulting Psychologists Press.

*Cardona, P., \& Elola, A. (2003, August). Trust in management: The effect of managerial trustworthy behavior and reciprocity. Paper presented at the annual meeting of the Academy of Management, Seattle, WA.

*Carson, S. J., Madhok, A., Varman, R., \& John, G. (2003). Information processing moderators of the effectiveness of trust-based governance in interfirm R\&D collaboration. Organization Science, 14, 45-56.

*Child, J., \& Mollering, G. (2003). Contextual confidence and active trust development in the Chinese business environment. Organization Science, 14, 69-80.

*Clegg, C., Unsworth, K., Epitropaki, O., \& Parker, G. (2002). Implicating trust in the innovation process. Journal of Occupational and Organizational Psychology, 75, 409-422.

*Colquitt, J. A., LePine, J. A., Piccolo, R. F., \& Rich, B. L. (2004). Justice, trust, and uncertainty: When does fair treatment matter most? Unpublished manuscript.

Cook, J., \& Wall, T. (1980). New work attitude measures of trust, organizational commitment and personal need non-fulfillment. Journal of Occupational Psychology, 53, 39-52.

Costa, P. T., Jr., \& McCrae, R. R. (1992). The NEO PI-R professional manual. Odessa, FL: Psychological Assessment Resources.

*Coyle-Shapiro, J. (2002). A psychological contract perspective on organizational citizenship behavior. Journal of Organizational Behavior, 23, 927-946.

*Cropanzano, R., Prehar, C., \& Chen, P. Y. (2002). Using social exchange theory to distinguish procedural from interactional justice. Group \& Organization Management, 27, 324-351.

Cummings, L. L., \& Bromiley, P. (1996). The organizational trust inventory (OTI): Development and validation. In R. M. Kramer \& T. R. Tyler (Eds.), Trust in organizations: Frontiers of theory and research (pp. 302-330). Thousand Oaks, CA: Sage.

*Currall, S. C., \& Judge, T. A. (1995). Measuring trust between organizational boundary role persons. Organizational Behavior and Human Decision Processes, 64, 151-170.

*Davids, A., \& Mahoney, J. T. (1957). Personality dynamics and accident proneness in an industrial setting. Journal of Applied Psychology, 41, 303-306.

*Davidson, M., \& Friedman, R. A. (1998). When excuses don't work: The persistent injustice effect among Black managers. Administrative Science Quarterly, 43, 154-183.

*Davis, J. H., Schoorman, F. D., Mayer, R. C., \& Tan, H. H. (2000). The trusted general manager and business unit performance: Empirical evidence of a competitive advantage. Strategic Management Journal, 21, 563-576.

*Deluga, R. J. (1995). The relation between trust in the supervisor and subordinate organizational citizenship behavior. Military Psychology, 7, $1-16$.

Deutsch, M. (1958). Trust and suspicion. Journal of Conflict Resolution, 2, 265-279.

Deutsch, M. (1960). The effect of motivational orientation upon trust and suspicion. Human Relations, 13, 123-139.

Dirks, K. T., \& Ferrin, D. L. (2002). Trust in leadership: Meta-analytic findings and implications for research and practice. Journal of Applied Psychology, 87, 611-628.

*Driscoll, J. W. (1978). Trust and participation in organizational decision making as predictors of satisfaction. Academy of Management Journal, $21,44-56$.

*Duffy, M. K., \& Ferrier, W. J. (2003). Birds of a feather? How supervisor-subordinate dissimilarity moderates the influence of supervisor behaviors on workplace attitudes. Group \& Organization Management, 28, 217-248.

*Earley, P. C. (1986). Trust, perceived importance of praise and criticism, and work performance: An examination of feedback in the United States and England. Journal of Management, 12, 457-473.

*Earley, P. C. (1988). Computer-generated performance feedback in the magazine-subscription industry. Organizational Behavior and Human Decision Processes, 41, 50-64.

*Eby, L. T., Adams, D. M., Russell, J., \& Gaby, S. H. (2000). Perceptions of organizational readiness for change: Factors related to employees' reactions to the implementation of team-based selling. Human Relations, 53, 419-442.

Eisenberger, R., Armeli, S., Rexwinkel, B., Lynch, P. D., \& Rhoades, L. (2001). Reciprocation of perceived organizational support. Journal of Applied Psychology, 86, 42-51.

*Ellison, C. W., \& Firestone, I. J. (1974). Development of interpersonal trust as a function of self-esteem target status and target style. Journal of Personality and Social Psychology, 29, 655-663.

*Elloy, D. E., Everett, J. E., \& Flynn, W. R. (1991). An examination of the correlates of job involvement. Group \& Organization Studies, 16, 160177.

*Farh, J., Tsui, A. S., Xin, K., \& Cheng, B. (1998). The influence of relational demography and guanxi: The Chinese case. Organization Science, 9, 471-488.

*Ferrin, D. L., \& Dirks, K. T. (2003). The use of rewards to increase and decrease trust: Mediating processes and differential effects. Organization Science, 14, 18-31.

*Ferrin, D. L., Dirks, K. T., \& Shah, P. P. (2003, August). Many routes toward trust: A social network analysis of the determinants of interpersonal trust. Paper presented at the annual meeting of the Academy of Management, Seattle, WA.

Flores, F., \& Solomon, R. C. (1998). Creating trust. Business Ethics Quarterly, 8, 205-232.

*Folger, R., \& Konovsky, M. A. (1989). Effects of procedural and distributive justice on reactions to pay raise decisions. Academy of Management Journal, 32, 115-130.

*Ford, C. M., \& Gioia, D. A. (2000). Factors influencing creativity in the domain of managerial decision making. Journal of Management, 26, 705-732.

*Freid, Y., Tiegs, R. B., \& Bellamy, A. R. (1992). Personal and interpersonal predictors of supervisors' avoidance of evaluating subordinates. Journal of Applied Psychology, 77, 462-468.

*Fulk, J., Brief, A. P., \& Barr, S. H. (1985). Trust-in-supervisor and 
perceived fairness and accuracy of performance evaluations. Journal of Business Research, 13, 299-313.

Gabarro, J. J. (1978). The development of trust, influence, and expectations. In A. G. Athos \& J. J. Gabarro (Eds.), Interpersonal behaviors: Communication and understanding in relationships (pp. 290-303). Englewood Cliffs, NJ: Prentice Hall.

Gabarro, J. J., \& Athos, J. (1976). Interpersonal relations and communications. Englewood Cliffs, NJ: Prentice Hall.

*Gaines, J. H. (1980). Upward communication in industry: An experiment. Human Relations, 33, 929-942.

Golembiewski, R. T., \& McConkie, M. (1975). The centrality of interpersonal trust in group processes. In C. L. Cooper (Ed.), Theories of group processes (pp. 131-185). New York: Wiley.

*Gopinath, C., \& Becker, T. E. (2000). Communication, procedural justice, and employee attitudes: Relationships under conditions of divestiture. Journal of Management, 26, 63-83.

*Gordon, L. V. (1973). The therapeutic personality in the therapeutic community. Journal of Applied Psychology, 58, 108-112.

Gouldner, A. W. (1960). The norm of reciprocity: A preliminary statement. American Sociological Review, 25, 161-178.

Govier, T. (1994). Is it a jungle out there? Trust, distrust and the construction of social reality. Dialogue, 33, 237-252.

*Gurtman, M. B., \& Lion, C. (1982). Interpersonal trust and perceptual vigilance for trustworthiness descriptors. Journal of Research in Personality, 16, 108-117.

*Hammer, T. H., \& Berman, M. (1981). The role of noneconomic factors in faculty union voting. Journal of Applied Psychology, 66, 415-421.

Hardin, R. (1996). Trustworthiness. Ethics, 107, 26-42.

*Hua, W. (2003, August). A social exchange model of subordinate's trust in supervisors. Paper presented at the annual meeting of the Academy of Management, Seattle, WA.

Hunter, J. E., \& Schmidt, F. L. (2004). Methods of meta-analysis. Newbury Park, CA: Sage.

*Jackson, C. L., Colquitt, J. A., Wesson, M. J., \& Zapata-Phelan, C. P. (2005). [Psychological collectivism, trust, and group member behaviors]. Unpublished raw data.

Jarvenpaa, S. L., Knoll, K., \& Leidner, D. E. (1998). Is anybody out there? Antecedents of trust in global virtual teams. Journal of Management Information Systems, 14, 29-64.

Jones, G. R., \& George, J. M. (1998). The experience and evolution of trust: Implications for cooperation and teamwork. Academy of Management Review, 23, 531-546.

*Jones, A. P., James, L. R., \& Bruni, J. R. (1975). Perceived leadership behavior and employee confidence in the leader as moderated by job involvement. Journal of Applied Psychology, 60, 146-149.

Jöreskog, K. G., \& Sörbom, D. (1996). LISREL (Version 8) [Computer software and manual]. Chicago: Scientific Software International.

Judge, T. A., Thoreson, C. J., Bono, J. E., \& Patton, G. K. (2001). The job satisfaction-job performance relationship: A qualitative and quantitative review. Psychological Bulletin, 127, 376-407.

*Jung, D. I., \& Avolio, B. J. (2000). Opening the black box: An experimental investigation of the mediating effects of trust and value congruence on transformational and transactional leadership. Journal of Organizational Behavior, 21, 949-964.

Kee, H. W., \& Knox, R. E. (1970). Conceptual and methodological considerations in the study of trust and suspicion. Journal of Conflict Resolution, 14, 357-366.

*Kegan, D. L., \& Rubenstein, A. H. (1973). Trust, effectiveness, and organizational development: A field study in R\&D. The Journal of Applied Behavioral Science, 9, 498-513.

*Kernan, M. C., \& Hanges, P. J. (2002). Survivor reactions to reorganization: Antecedents and consequences of procedural, interpersonal, and informational justice. Journal of Applied Psychology, 87, 916-928.

*Kim, P. H., Ferrin, D. L., Cooper, C. D., \& Dirks, K. T. (2003, August).
Removing the shadow of suspicion: The effects of apology versus denial for repairing ability versus integrity-based trust violations. Paper presented at the annual meeting of the Academy of Management, Seattle, WA.

*Kim, W. C., \& Mauborgne, R. A. (1993). Procedural justice, attitudes, and subsidiary top management compliance with multinationals' corporate strategic decisions. Academy of Management Journal, 36, 502-526.

*Kirkpatrick, S. A., \& Locke, E. A. (1996). Direct and indirect effects of three core charismatic leadership components on performance and attitudes. Journal of Applied Psychology, 81, 36-51.

Kline, R. B. (2005). Principles and practices of structural equation modeling (2nd ed.). New York: Guilford Press.

*Koberg, C. S., Boss, R. W., Chappell, D., \& Ringer, R. C. (1994). Correlates and consequences of protégé mentoring in a large hospital. Group \& Organization Management, 19, 219-239.

*Koberg, C. S., Boss, R. W., Senjem, J. C., \& Goodman, E. A. (1999). Antecedents and outcomes of empowerment. Group \& Organization Management, 24, 71-91.

*Konovsky, M. A., \& Cropanzano, R. (1991). Perceived fairness of employee drug testing as a predictor of employee attitudes and job performance. Journal of Applied Psychology, 76, 698-707.

*Konovsky, M. A., \& Pugh, S. D. (1994). Citizenship behavior and social exchange. Academy of Management Journal, 37, 656-669.

*Korsgaard, M. A., Brodt, S. E., \& Whitener, E. M. (2002). Trust in the face of conflict: The role of managerial trustworthy behavior and organizational context. Journal of Applied Psychology, 87, 312-319.

*Korsgaard, M. A., Roberson, L., \& Rymph, R. D. (1998). What motivates fairness? The role of subordinate assertive behavior on managers' interactional fairness. Journal of Applied Psychology, 83, 731-744.

*Korsgaard, M. A., Sapienza, H. J., \& Schweiger, D. M. (2002). Beaten before begun: The role of procedural justice in planning change. Journal of Management, 28, 497-516.

*Kramer, R. M. (1994). The sinister attribution error: Paranoid cognition and collective distrust in organizations. Motivation and Emotion, 18, $199-230$.

Kramer, R. M. (1999). Trust and distrust in organizations: Emerging perspectives, enduring questions. Annual Review of Psychology, 50, $569-598$

*Kumar, P., \& Ghadially, R. (1989). Organizational politics and its effects on members of organizations. Human Relations, 4, 305-314.

*Lagace, R. R. (1991). An exploratory study of reciprocal trust between sales managers and salespersons. Journal of Personal Selling \& Sales Management, 2, 49-58.

*Lee, C., \& Farh, J. (1999). The effects of gender in organizational justice perception. Journal of Organizational Behavior, 20, 133-143.

*Lee, C., Pillutla, M., \& Law, K. S. (2000). Power-distance, gender, and organizational justice. Journal of Management, 26, 685-704

Lee, K., \& Allen, N. J. (2002). Organizational citizenship behavior and workplace deviance: The role of affect and cognitions. Journal of Applied Psychology, 87, 131-142.

Lehman, W. E. K., \& Simpson, D. D. (1992). Employee substance abuse and on-the-job behaviors. Journal of Applied Psychology, 77, 309-321.

Leventhal, G. S. (1980). What should be done with equity theory? New approaches to the study of fairness in social relationships. In K. Gergen, M. Greenberg, \& R. Willis (Eds.), Social exchange: Advances in theory and research (pp. 27-55). New York: Plenum Press.

Lewicki, R. J., \& Bunker, B. B. (1996). Developing and maintaining trust in work relationships. In R. M. Kramer \& T. R. Tyler (Eds.), Trust in organizations: Frontiers of theory and research (pp. 114-139). Thousand Oaks, CA: Sage.

Lewis, J. D., \& Weigert, A. (1985). Trust as a social reality. Social Forces, 63, 967-985.

Lind, E. A. (2001). Fairness heuristic theory: Justice judgments as pivotal cognitions in organizational relations. In J. Greenberg \& R. Cropanzano 
(Eds.), Advances in organizational justice (pp. 56-88). Stanford, CA: Stanford University Press.

*Lui, S. S., \& Ngo, H. (2004). The role of trust and contractual safeguards on cooperation in non-equity alliances. Journal of Management, 30, $471-485$.

*Luo, Y. (2002). Building trust in cross-cultural collaborations: Toward a contingency perspective. Journal of Management, 28, 669-694.

*Lynch, P. D., Eisenberger, R., \& Armeli, S. (1999). Perceived organizational support: Inferior versus superior performance by wary employees. Journal of Applied Psychology, 84, 467-483.

*MacDonald, A. P., Kessel, V. S., \& Fuller, J. B. (1972). Self-disclosure and two kinds of trust. Psychological Reports, 30, 143-148.

*MacKenzie, S. B., Podsakoff, P. M., \& Rich, G. A. (2001). Transformational and transactional leadership and salesperson performance. Journal of the Academy of Marketing Science, 29, 115-134.

*Magner, N., Welker, R. B., \& Johnson, G. G. (1996). The interactive effects of participation and outcome favorability on turnover intentions and evaluations of supervisors. Journal of Occupational and Organizational Psychology, 69, 135-143.

*Mayer, R. C., \& Davis, J. H. (1999). The effect of the performance appraisal system on trust for management: A field quasi-experiment. Journal of Applied Psychology, 84, 123-136.

Mayer, R. C., Davis, J. H., \& Schoorman, F. D. (1995). An integrative model of organizational trust. Academy of Management Review, 20, 709-734.

*Mayer, R. C., \& Gavin, M. B. (2005). Trust in management and performance: Who minds the shop while the employees watch the boss? Academy of Management Journal, 48, 874-888.

McAllister, D. J. (1995). Affect- and cognition-based trust as foundations for interpersonal cooperation in organizations. Academy of Management Journal, 38, 24-59.

McAllister, D. J. (1997). The second face of trust: Reflections on the dark side of interpersonal trust in organizations. In R. J. Lewicki, R. J. Bies, \& B. H. Sheppard (Eds.), Research on negotiation in organizations (Vol. 6, pp. 87-111). Greenwich, CT: JAI Press.

*McEvoy, G. M. (1997). Organization change and outdoor management education. Human Resource Management, 36, 235-250.

McKnight, D. H., Cummings, L. L., \& Chervany, N. L. (1998). Initial trust formation in new organizational relationships. Academy of Management Review, 23, 473-490.

Meyer, J. P., \& Allen, N. J. (1997). Commitment in the workplace: Theory, research, and application. Thousand Oaks, CA: Sage.

Meyer, J. P., Stanley, D. J., Herscovitch, L., \& Topolnytsky, L. (2002). Affective, continuance, and normative commitment to the organization: A meta-analysis of antecedents, correlates, and consequences. Journal of Vocational Behavior, 61, 20-52.

Mishra, A. K., \& Mishra, K. E. (1994). The role of mutual trust in effective downsizing strategies. Human Resource Management, 33, 261-279.

*Moorman, C., Zaltman, G., \& Deshpande, R. (1992). Relationships between providers and users of market research: The dynamics of trust within and between organizations. Journal of Marketing Research, 29, 314-328.

Mowday, R. T., Porter, L. W., \& Steers, R. M. (1982). Employeeorganization linkages: The psychology of commitment, absenteeism, and turnover. New York: Academic Press.

Mowday, R. T., Steers, R. M., \& Porter, L. W. (1979). The measurement of organizational commitment. Journal of Vocational Behavior, 14, 224-247.

*Naquin, C. E., \& Paulson, G. D. (2003). Online bargaining and interpersonal trust. Journal of Applied Psychology, 88, 113-120.

*Ng, K., \& Chua, R. Y. J. (2003, August). Do I contribute more when I trust more? A study on two boundary conditions of trust. Paper presented at the annual meeting of the Academy of Management, Seattle, WA.

*Nooteboom, B., Berger, H., \& Noorderhaven, N. G. (1997). Effects of trust and governance on relational risk. Academy of Management Journal, 40, 308-338.

*Oldham, G. R. (1975). The impact of supervisory characteristics on goal acceptance. Academy of Management Journal, 18, 461-475.

*O'Reilly, C. A. (1978). The intentional distortion of information in organizational communication: A laboratory and field investigation. Human Relations, 31, 173-193.

*O'Reilly, C. A., \& Anderson, J. C. (1979). Trust and the communication of performance appraisal information: The effect of feedback on performance and job satisfaction. Human Communication Research, 6, 289 298.

Ostroff, C., \& Harrison, D. A. (1999). Meta-analysis, level of analysis, and best estimates of population correlations: Cautions for interpreting metaanalytic results in organizational behavior. Journal of Applied Psychology, 84, 260-270.

*Pearce, J. L. (1993). Toward an organizational behavior of contract laborers: Their psychological involvement and effects on employee co-workers. Academy of Management Journal, 36, 1082-1096.

*Pearce, J. L., Branyiczki, I., \& Bigley, G. A. (2000). Insufficient bureaucracy: Trust and commitment in particularistic organizations. Organization Science, 11, 148-162.

*Pettit, J. D., Jr., Goris, J. R., \& Vaught, B. C. (1997). An examination of organizational communication as a moderator of the relationship between job performance and job satisfaction. Journal of Business Communication, 34, 81-98.

*Piccolo, R. F., \& Colquitt, J. A. (2005). [Transformational leadership, trust, and job behaviors]. Unpublished raw data, University of Florida.

*Pillai, R., Schriesheim, C. A., \& Williams, E. S. (1999). Fairness perceptions and trust as mediators for transformational and transactional leadership: A two-sample study. Journal of Management, 25, 897-933.

*Podsakoff, P. M., MacKenzie, S. B., \& Bommer, W. H. (1996). Transformational leader behaviors and substitutes for leadership as determinants of employee satisfaction, commitment, trust, and organizational citizenship behaviors. Journal of Management, 22, 259-298.

*Podsakoff, P. M., MacKenzie, S. B., Moorman, R. H., \& Fetter, R. (1990). Transformational leader behaviors and their effects on followers' trust in leader, satisfaction, and organizational citizenship behaviors. Leadership Quarterly, 1, 107-142.

*Puffer, S. M. (1987). Prosocial behavior, noncompliant behavior, and work performance among commission salespeople. Journal of Applied Psychology, 72, 615-621.

Read, W. H. (1962). Upward communication in industrial hierarchies. Human Relations, 3-16.

*Rich, G. A. (1997). The sales manager as a role model: Effects on trust, job satisfaction, and performance of salespeople. Journal of the Academy of Marketing Science, 25, 319-328.

Riker, W. H. (1971). The nature of trust. In J. T. Tedeschi (Ed.), Perspectives on social power (pp. 63-81). Chicago: Aldine.

Roberts, K. H., \& O'Reilly, C. A. (1974). Measuring organizational communication. Journal of Applied Psychology, 59, 321-326.

*Robinson, S. L. (1996). Trust and breach of the psychological contract. Administrative Science Quarterly, 41, 574-599.

Robinson, S. L., \& O'Leary-Kelly, A. M. (1998). Monkey see, monkey do: The influence of work groups on the antisocial behavior of employees. Academy of Management Journal, 41, 658-672.

*Robinson, S. L., \& Rousseau, D. M. (1994). Violating the psychological contract: Not the exception but the norm. Journal of Organizational Behavior, 15, 245-259.

*Robinson, S. L., \& Wolfe-Morrison, E. (1995). Psychological contracts and OCB: The effect of unfulfilled obligations on civic virtue behavior. Journal of Organizational Behavior, 16, 289-298.

Rosenberg, M. (1956). Misanthropy and political ideology. American Sociological Review, 21, 690-695.

Ross, W., \& LaCroix, J. (1996). Multiple meanings of trust in negotiation 
theory and research: A literature review and integrative model. International Journal of Conflict Management, 7, 314-360.

Rotter, J. B. (1967). A new scale for the measurement of interpersonal trust. Journal of Personality, 35, 651-665.

Rotter, J. B. (1971). Generalized expectancies for interpersonal trust. American Psychologist, 26, 443-452.

Rotter, J. B. (1980). Interpersonal trust, trustworthiness, and gullibility. American Psychologist, 35, 1-7.

Rotundo, M., \& Sackett, P. R. (2002). The relative importance of task, citizenship, and counterproductive performance to global ratings of job performance: A policy-capturing approach. Journal of Applied Psychology, 87, 66-80.

Rousseau, D. M., Sitkin, S. B., Burt, R. S., \& Camerer, C. (1998). Not so different after all: A cross-discipline view of trust. Academy of Management Review, 23, 393-404.

*Rousseau, D. M., \& Tijoriwala, S. A. (1999). What's a good reason to change? Motivated reasoning and social accounts in promoting organizational change. Journal of Applied Psychology, 84, 514-528.

Rynes, S. L. (1991). Recruitment, job choice, and post-hire consequences: A call for new research directions. In M. D. Dunnette \& L. M. Hough (Eds.), Handbook of industrial and organizational psychology (Vol. 2, pp. 399-444). Palo Alto, CA: Consulting Psychologists Press.

Sackett, P. R., \& DeVore, C. J. (2001). Counterproductive behaviors at work. In N. Anderson, D. S. Ones, H. K. Sinangil, \& C. Viswesvaran (Eds.), Handbook of industrial, work, and organizational psychology (Vol. 1, pp. 145-151). Thousand Oaks, CA: Sage.

Salas, E., Rozell, D., Mullen, B., \& Driskell, J. E. (1999). The effect of team building on performance: An integration. Small Group Research, 30, 309-329.

*Sanchez, R. J., Olsen-Buchanan, J. B., Rechner, P. L., \& Schmidtke, J. M. (2003, August). The effects of dispositional trust and team-member exchange in the virtual environment. Paper presented at the annual meeting of the Academy of Management, Seattle, WA

*Sapienza, H. J., \& Korsgaard, M. A. (1996). Procedural justice in entrepreneur-investor relations. Academy of Management Journal, 3, $544-574$

*Schindler, P. L., \& Thomas, C. C. (1993). The structure of interpersonal trust in the workplace. Psychological Reports, 73, 563-573.

Schmidt, F. L., \& Hunter, J. E. (2000). Select on intelligence. In E. A. Locke (Ed.), Blackwell handbook of principles of organizational behavior (pp. 3-8). Malden, MA: Blackwell.

*Schoorman, D. F., Mayer, R. C., \& Davis, J. H. (1996, April). Empowerment in veterinary clinics: The role of trust in delegation. Paper presented at the annual meeting of the Society of Industrial and Organizational Psychology, San Diego, CA.

*Schweiger, D. M., \& Denisi, A. S. (1991). Communication with employees following a merger: A longitudinal field experiment. Academy of Management Journal, 34, 110-135.

*Shamir, B., Zakay, E., Breinin, E., \& Popper, M. (1998). Correlates of charismatic leader behavior in military units: Subordinates' attitudes, unit characteristics, and superiors' appraisals of leader performance. Academy of Management Journal, 41, 387-409.

Shapiro, D., Sheppard, B. H., \& Cheraskin, L. (1992, October). Business on a handshake. The Negotiation Journal, 8, 365-378.

Shore, L. M., Tetrick, L. E., Lynch, P., \& Barksdale, K. (2006). Social and economic exchange: Construct development and validation. Journal of Applied Social Psychology, 36, 837-867.

Sitkin, S. B., \& Roth, N. L. (1993). Explaining the limited effectiveness of legalistic "remedies" for trust/distrust. Organization Science, 4, 367392

Skarlicki, D. P., \& Latham, G. P. (1996). Increasing citizenship behavior within a labor union: A test of organizational justice theory. Journal of Applied Psychology, 81, 161-169.

Smith, C. A., Organ, D. W., \& Near, J. P. (1983). Organizational citizen- ship behavior: Its nature and antecedents. Journal of Applied Psychology, 68, 653-663.

*Spreitzer, G. M., \& Mishra, A. K. (2002). To stay or to go: Voluntary survivor turnover following an organizational downsizing. Journal of Organizational Behavior, 23, 707-729.

Stack, L. C. (1978). Trust. In H. London \& J. E. Exner, Jr. (Eds.), Dimensionality of personality (pp. 561-599). New York: Wiley.

*Stewart, K. J., \& Zhang, Y. (2003, August). The role of hypertext links in building and degrading trust. Paper presented at the annual meeting of the Academy of Management, Seattle, WA.

Stone-Romero, E. F., \& Rosopa, P. J. (2004). Inference problems with hierarchical multiple regression-based tests of mediating effects. In J. Martocchio (Ed.), Research in personnel and human resources management (Vol. 23, pp. 249-290). Oxford, England: Elsevier.

*Strutton, D., Toma, A., \& Pelton, L. E. (1993). Relationship between psychological climate and trust between salespersons and their managers in sales organizations. Psychological Reports, 72, 931-939.

*Tan, H. H., \& Tan, C. S. F. (2000). Toward the differentiation of trust in supervisor and trust in organization. Genetic, Social, and General Psychology Monographs, 126, 241-260.

*Thompson, N. J., Raftery, J., \& Thompson, K. E. (2003). Client conditions of trust, within virtual organizations: An application of Butler's Conditions of Trust Inventory in the UK construction sector. Unpublished manuscript, Middlesex University Business School, Hendon, London.

*Tjosvold, D., Andrews, I. R., \& Struthers, J. T. (1991). Power and interdependence in work groups. Group \& Organization Studies, 16, 285-299.

*Treadway, D. C., Hochwarter, W. A., Ferris, G. R., Kacmar, C. J., Douglas, C., \& Ammeter, A. P. (2004). Leader political skill and employee reactions. Leadership Quarterly, 15, 493-513.

Turnley, W. H., Bolino, M. C., Lester, S. W., \& Bloodgood, J. M. (2003). The impact of psychological contract fulfillment on the performance of in-role and organizational citizenship behaviors. Journal of Management, 29, 187-206.

*Tyler, T. R., \& Degoey, P. (1995). Collective restraint in social dilemmas: Procedural justice and social identification effects on support for authorities. Journal of Personality and Social Psychology, 69, 482-497.

Tyler, T. R., \& Lind, E. A. (1992). A relational model of authority in groups. In M. P. Zanna (Ed.), Advances in experimental social psychology (Vol. 25, pp. 115-191). San Diego, CA: Academic Press.

Van Dyne, L., \& LePine, J. A. (1998). Helping and voice extra-role behavior: Evidence of construct and predictive validity. Academy of Management Journal, 41, 108-119.

*Van Dyne, L., Vandewalle, D., Kostova, T., Latham, M. E., \& Cummings, L. L. (2000). Collectivism, propensity to trust and self-esteem as predictors of organizational citizenship in a non-work setting. Journal of Organizational Behavior, 21, 3-23.

*Vigoda-Gadot, E. (2003, August). Managerial quality, administrative performance, and citizens' trust in governance: Can we point to causality? Paper presented at the annual meeting of the Academy of Management, Seattle, WA.

Viswesvaran, C., \& Ones, D. S. (1995). Theory testing: Combining psychometric meta-analysis and structural equations modeling. Personnel Psychology, 48, 865-885.

Wageman, R. (2001). The meaning of interdependence. In M. E. Turner (Ed.), Groups at work: Theory and research (pp. 197-217). Mahwah, NJ: Erlbaum.

*Wagner, S. L., \& Rush, M. C. (2000). Altruistic organizational citizenship behavior: Context, disposition, and age. Journal of Social Psychology, 140, 379-391.

Wayne, S. J., Shore, L. M., \& Liden, R. C. (1997). Perceived organizational support and leader-member exchange: A social exchange perspective. Academy of Management Journal, 40, 82-111. 
Webb, W. M., \& Worchel, P. (1986). Trust and distrust. In S. Worchel \& W. G. Austin (Eds.), Psychology of intergroup relations (pp. 213-228). Chicago: Nelson-Hall.

Whitener, E. M. (1990). Confusion of confidence intervals and credibility intervals in meta-analysis. Journal of Applied Psychology, 75, 315-321.

*Wild, R. E. (2004). Trust in urgent moments: An exploration of trust among firefighters. Unpublished doctoral dissertation, University of Florida.

*Williams, K. D., \& Karau, S. J. (1991). Social loafing and social compensation: The effects of expectations of co-worker performance. Journal of Personality and Social Psychology, 61, 570-581.

Williams, L. J., \& Anderson, S. E. (1991). Job satisfaction and organizational commitment as predictors of organizational citizenship behaviors. Journal of Management, 17, 601-617.

Williams, M. (2001). In whom we trust: Group membership as an affective context for trust development. Academy of Management Review, 26, 377-396.

*Yamagishi, T. (1986). The provision of a sanctioning system as a public good. Journal of Personality and Social Psychology, 51, 110-116.

*Yoon, M. H., \& Suh, J. (2003). Organizational citizenship behaviors and service quality as external effectiveness of contact employees. Journal of Business Research, 56, 597-611.

*Young, A. M., \& Perrewe, P. L. (2000). What did you expect? An examination of career-related support and social support among mentors and protégés. Journal of Management, 26, 611-632.

*Zaheer, A., McEvily, B., \& Perrone, V. (1998). Does trust matter? Exploring the effects of interorganizational and interpersonal trust on performance. Organization Science, 9, 141-159.

Zand, D. E. (1972). Trust and managerial problem solving. Administrative Science Quarterly, 17, 229-239.

*Zapata-Phelan, C. P., \& Colquitt, J. A. (2005). [Personality, stressors, trust, and job behaviors]. Unpublished raw data, University of Florida.

*Zeitz, G., Johannesson, R., \& Ritchie, J. E., Jr. (1997). An employee survey measuring total quality management practices and culture. Group \& Organization Management, 22, 414-444.

Received September 28, 2005

Revision received October 3, 2006

Accepted December 19, 2006

\section{ORDER FORM}

Start my 2007 subscription to the Journal of Applied

Psychology! ISSN: 0021-9010

\section{\$92.00, APA Member/Affiliate \\ \$198.00, Individual NonMember \\ $\$ 598.00$, Institution \\ In DC add $5.75 \%$ / In MD add $5 \%$ sales tax} Total Amount Enclosed

Subscription orders must be prepaid. (Subscriptions are on a calendar year basis only.) Allow 4-6 weeks for delivery of the first issue. Call for international subscription rates.

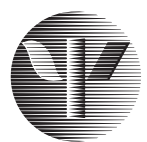

AMERICAN PSYCHOLOGICAL ASSOCIATION

\section{SEND THIS ORDER FORM TO:}

American Psychological Association

Subscriptions

750 First Street, NE

Washington, DC 20002-4242

Or call 800-374-2721, fax 202-336-5568.

TDD/TTY 202-336-6123.

For subscription information, e-mail: subscriptions@apa.org
Check enclosed (make payable to APA)

\section{Charge my: OVISA $\bigcirc$ MasterCard $\bigcirc$ American} Express

Cardholder Name

Card No Exp. Date

\section{BILLING ADDRESS:}

Street

City _ State __ Zip _

Daytime Phone

E-mail

MAIL TO:

Name

Address

$\begin{array}{ll}\text { City } & \text { State } \_ \text {Zip } \_ \text {APLAI } \\ \text { APA Member \# } & \end{array}$

